\title{
THE INFORMATION REVOLUTION REACHES PHARMACEUTICALS: BALANCING INNOVATION INCENTIVES, COST, AND ACCESS IN THE POST-GENOMICS ERA
}

Arti K. Rai*

\begin{abstract}
Recent development in genomics - the science that lies at the intersection of information technology and biotechnology - have ushered in a new era of pharmaceutical innovation. Professor Rai advances a theory of pharmaceutical development and allocation that takes account of these recent developments from the perspective of both patent law and health law - that is, from both the production side and the consumption side. She argues that genomics has the potential to make reforms that increase access to prescription drugs not only more necessary as a matter of equity but also more feasible as a matter of innovation policy. On the production end, so long as patent rights in upstream genomics research do not create transaction cost bottlenecks, genomics should, in the not-too-distant future, yield some reduction in drug research and development costs. If these cost reductions are realized, it may be possible to scale back certain features of the pharmaceutical patent regime that cause patent protection for pharmaceuticals to be significantly stronger than patent protection for other innovation. On the consumption side, genomics should make drug therapy even more important in treating illness. This reality, coupled with empirical data revealing that cost and access problems are particularly severe for those individuals who are not able to secure favorable price discrimination through insurance, militates in favor of government subsidies for such insurance. As contrasted with patent buyouts, the approach favored by many patent scholars, subsidies
\end{abstract}

* Associate Professor of Law, University of San Diego Law School; Visiting Associate Professor, Washington University, St. Louis Law School (Spring 2001).

I thank Ian Ayres, Stuart Benjamin, Bob Hunt, William Sage, and Jay Thomas for valuable comments and the University of San Diego Law School for research support. Earlier versions of this article were presented at the University of Pennsylvania Law School, the UT/UC Berkeley Advanced Patent Law Institute, the University of Pennsylvania Center for Bioethics, the 21st Annual Health Law Teachers' Conference, and the University of Illinois Law School. 
would take account of, and indeed capitalize on, the institutional realities of health care consumption. These subsidies should, however, be linked to insurance regulation that works to channel innovation in a cost-effective direction by requiring coverage of drugs that provide significant benefit relative to their cost.

At a recent White House ceremony, Francis Collins of the publicly funded Human Genome Project and Craig Venter of the private company Celera announced that they had completed a sequence of the human genome. ${ }^{1}$ Although the sequencing milestone is largely symbolic, what we will learn from the human genome (and from the genomes of other organisms) in years to come is far from symbolic. As various pundits have observed, the science of genomics, which applies information technology to the vast amount of genome data currently being generated, ${ }^{2}$ will usher in a new era of pharmaceutical innovation. ${ }^{3}$ In this new era, biological research will be driven by data. As a consequence, researchers should be able to develop drugs in a faster, more streamlined fashion, through computerized analysis of the genes, proteins, and bio-

1. E.g., Nicholas Wade, Scientists Complete Rough Draft of Genome, N.Y. TimEs, June 27, 2000, at A1.

2. It is estimated that the amount of biomedical data available increases tenfold every five years. See Jon Cohen, The Genomics Gamble, 275 SCIENCE 767, 768 (1997). Thus, for example, scientists now have one thousand times as much data as they did in 1985. See also David J. Lockhart \& Elizabeth A. Winzeler, Genomics, Gene Expression, and DNA Arrays, 405 NATURE 827, 827 (2000) ("Biological and biomedical research is in the midst of a significant transition that is being driven by two primary factors: the massive increase in the amount of DNA sequence information and the development of technologies to exploit its use."); Ognjenka Goga Vukmirovic \& Shirley M. Tilghman, Exploring Genome Space, 405 NATURE 820, 820 (2000) (noting that biology is "moving from being largely a data-poor science to becoming a data-rich science"). In the past few years, over thirty organisms have had their genomes completely sequenced; the sequencing of more than one hundred organisms is in progress. See Lockhart \& Winzeler, supra, at 827; see also Eric S. Lander, Genomics: Launching a Revolution in Medicine, 28:4 J.L. MED. \& ETHICs 7 (Special Supp. 2000) (noting that the genome is biology's equivalent of the periodic table of elements). Current applications of information technology to genomic data include: DNA database searches that find particular genes or generate functional information on raw genetic data, see Scott Hensley, New Race Heats Up to Turn Gene Information Into Drug Discoveries, WALL ST. J., June 26, 2000, at B1; gene expression studies that use DNA chips to determine what genes are expressed by particular cells, see Bertrand R. Jordan, 'Genomics': Buzzword or Reality, 6 J. BIOMEDICAL SCI. 145 (1999); structural genomics, which aims to determine the function of the proteins encoded by particular genes by examining the threedimensional structure of these proteins, see Andrew Pollack, The Next Chapter in the Book of Life is Written in the Proteins, N.Y. TIMES, July 4, 2000, at D1; and pharmacogenomics, which incorporates information about human genome variation into the design of "precision" drugs without side effects, see infra note 80 and accompanying text. On occasion, the fusion of information technology and biotechnology is also referred to as bioinformatics. See HOOMAN H. RASHIDI \& LUKAS K. BUEHLER, Bioinformatics Basics: ApPlication IN THE Biological ScienCE AND MEdicine 2 (2000). For purposes of this paper, I will use the terms "genomics" and "bioinformatics" interchangeably.

3. Craig Venter himself recently observed that "[t]he power and effectiveness of clinical pharmacology are about to be transformed with a speed that earlier in the decade could not have been foreseen even by the most astute visionaries." S. Broder \& J.C. Venter, Sequencing the Entire Genomes of Free-Living Organisms: The Foundation of Pharmacology in the New Millennium, 40 ANN. REV. PHARMACOLOGY \& TOXICOLOGY 97 (2000). 
chemical pathways that cause particular diseases. ${ }^{4}$ Indeed, to the extent that the efficiency gains achieved in the digital economy can be internalized by the biotechnology and pharmaceutical industries, innovation in these industries may, in the future, no longer be the uniquely expensive and risky process that it currently is. ${ }^{5}$

The genomics revolution should also increase significantly the role of prescription drugs in health care delivery. In all likelihood, because of exponential increases in genetic knowledge, drugs based on such knowledge will be able to address the root causes of a wide spectrum of common illnesses that are currently treated incompletely at best - everything from manic depression and heart disease to diabetes and cancer. ${ }^{6}$ Even now, as genomics-based drugs are just beginning to emerge, ${ }^{7}$ prescription

4. See Amy Barrett, The Genome Gold Rush: Pharma Frenzy, Bus. WK., June 12, 2000, at 160 (noting that genomics is changing the entire business model for pharmaceutical companies); Kenneth Chang, Incomplete, Project is Already Paying Off, N.Y. Times, June 27, 2000, at D1 (observing that "[e]ven incomplete, the databases of DNA sequences are a treasure trove for researchers, providing answers in a few minutes at a computer terminal rather than after months of laborious, expensive laboratory experiments"). Identifying the gene or genes associated with a disease is typically the first step in developing a therapy for the disease. Researchers then work to determine the structure and function of the protein produced by the gene and the regulatory pathways in which the protein is involved. The gene, a protein produced by the gene, or another protein in the relevant biological pathway can serve as the "target" for the therapy. See John Carey, The Genome Gold Rush: Who Will Be the First to Hit Pay Dirt?, Bus. WK., June 12, 2000, at 146 (discussing emerging field of "proteonomics"); Blaise Zerega, New Opportunities for Biotech Firms Are Emerging in Cells, Proteins, and Pharmacogenomics, RED HERRING, Apr. 1, 1999, available at 1999 WL 19627909, at *2-5 (discussing the need to integrate genetic knowledge with knowledge of the protein for which the gene codes and the cell in which the protein operates). In the entire history of the pharmaceutical industry, only about five hundred or so targets have been generated. By contrast, genomics is likely to generate tens of thousands of such targets. For further discussion of how genomics knowledge leads to drug development, see infra Part II.A.

5. See Richard DiMarchi, Group Vice President, Research Technologies and Product Development, Lilly Research Labs, in CONVERGENCE, ERNST \& YounG'S BIOTECHNOLOGY INDUSTRY REPORT, MILLENNIUM EDITION 41 (2000), available at http:/www.ey.com/global/gcr.nsf/US/LibraryHealth_Care-Ernst_\&_Young_LLP (last visited Feb. 27, 2001) (noting that the "emergence and convergence of pharmaceutical and information technologies provides the greatest basis for optimism in the face of ... increasing cost pressures"). David Lockhart and Elizabeth Winzeler of the Novartis Research Foundation's Genomics Institute recently observed that "[w]e expect that the pattern of development ... will be similar to that seen for computers and other high-tech electronics, which started out in the hands of the few developers and early adapters, and then moved quickly to become easier to use, more available, less expensive, and more powerful." Lockhart \& Winzeler, supra note 2, at 835.

6. E.g., Nicholas Wade, Now the Hard Part: Putting the Genome to Work, N.Y. TIMES, June 27, 2000 , at F1 (quoting Emory University medical geneticist as saying that genomics will "revolutionize medicine because ... [w]e will understand the mechanism of disease sufficiently to do rational therapy"); see also Jeffrey Hanke, Genomics and New Technologies as Catalysts for Change in the Drug Discovery Paradigm, 28:4 J.L. MED. \& ETHICS 15, 17 (Special Supp. 2000) (observing that genomics has already identified thousands of targets for drug discovery, while for the last thirty years the pharmaceutical industry has pursued only about five hundred targets).

7. Prescription drugs that are the product of genomics knowledge can be produced either by biotechnology companies or by pharmaceutical companies. Indeed, as pharmaceutical innovation has become increasingly dependent on genomics, see ERNST \& YOUNG, BIOTECH 99: BRIDGING THE GAP 31 (1999), available at http://www.ey.com/global/gcr.nsf/US/Library-Health_Care-Ernst_\&_Young LLP (last visited Feb. 27, 2001) [hereinafter BIOTECH 99] (noting comment by Peter Ringrose, President of the Bristol-Myers Squibb Pharmaceutical Research Institute that "[a]lmost $60 \%$ of the targets [for drug development] that we have at Bristol-Myers Squibb now come from genomic databases"), the division between biotechnology and "big pharma" has become blurry. In some cases, we see com- 
drugs occupy a prominent role in health care delivery. Spending on drugs rose $17.4 \%$ in 1999 (a rate approximately three times that of general health care inflation $)^{8}$ and is expected to grow at a similar pace in the future. Almost two-thirds of the increase in spending can be traced to the influx of drugs introduced in or after 1992.9 Drug cost increases are

plete vertical integration. Thus, for example, pharmaceutical companies may conduct upstream genomics research in-house or may acquire biotechnology concerns that do such research. See Feliza Mirasol, Biotech Industry's Mergers and Acquisitions Accelerate, CHEMICAL MARKET REP., Apr. 10, 2000. Conversely, biotechnology companies that have substantial patent portfolios on upstream research may conduct downstream clinical trials on genomics-derived drugs. See A.G. Edwards Investment Report (discussing clinical trials by Human Genome Sciences, Inc.). Where pharmaceutical and biotechnology companies have stopped short of complete integration, they have formed strategic alliances of various sorts. See generally Gregory B. Abbott, Joint Ventures and Collaborative Agreements for Developing and Commercializing Technology in the Life Sciences, 1193 PLVCORP. 247 (2000); see also BIOTECH 99, supra, at 20 (discussing strategy to "license as many efforts as possible from the biotech sector").

One regulatory distinction between the types of therapeutic agents traditionally produced by pharmaceutical companies and those produced by biotechnology companies merits attention, however. While the Food and Drug Administration (FDA) typically classifies the products of pharmaceutical companies as "drugs," it has often classified the products of biotechnology companies as "biologics." See 42 U.S.C. $\$ 262$ (1994). The latter category, which encompasses biological molecules such as vaccines, was developed in response to some highly publicized cases of vaccine impurity that arose in the early and mid-twentieth century. As a consequence, biologics face a more stringent regulatory approval process than do drugs. See generally Gary E. Gamerman, Regulation of Biologics Manufacturing: Questioning the Premise, 49 FOOD \& DRUG L.J. 213 (1994).

This paper will focus on the regulatory framework surrounding ordinary drugs. Nonetheless, it is worth emphasizing that the distinctions between drugs and "modern biologics" such as proteins, genes, and monoclonal antibodies are increasingly elusive (even for FDA regulators), see id. at 221, 227-29, and that modern biologics should probably be regulated like ordinary drugs. See id. at 233-34. This is particularly the case because, as matters currently stand, laws that encourage generic competition, see infra notes 40-51 and accompanying text, do not apply to biologics. See Andrew Pollack, Biotechnology Companies Try to Ward Off Generic Drugs, N.Y. TIMES, Dec. 28, 2000, at C1. A16.

8. See Robert Pear, $17 \%$ Rise in Drug Costs Hits Elderly Hardest, N.Y. TIMES, June 27, 2000, at

9. See Dep't of Health \& Human Servy., Report to the President on Prescription Drug Coverage, Utilization, and PRICES 93 (2000) [hereinafter HHS RePORT] (attributing twenty-three percent of the rise in drug spending to increased utilization of "new" drugs - that is, drugs introduced in or after 1992 - and forty-two percent of the rise to higher prices for those new drugs, for a total of sixty-five percent). In 1998, the average price per prescription for a new drug was $\$ 71.49$, more than twice the average price of $\$ 30.47$ for previously existing drugs. See NAT'L INST. FOR Health Care Mgmt., Factors AfFecting the Growth of Prescription Drug Expenditures, at $\mathbf{v}$ [hereinafter NIHCM REPORT]. As discussed further, infra notes 26-61 and accompanying text, new drugs typically cost more than old drugs simply because they enjoy patent protection. In addition, increased advertising by pharmaceutical companies has contributed to increased demand for drugs. See Milt Freudenheim, Group Seeks to Counteract Drugmakers: Health Providers Assail Consumer Advertising, N.Y. TIMES, June 30,2000, at C1 (noting arguments by health plans and employers that pharmaceutical companies' 1999 advertising budget of $\$ 13.9$ billion contributed to spending on drugs that were ineffective or inappropriate). For example, the ten most heavily advertised drugs accounted for twenty-two percent of the increase in prescription drug costs between 1993 and 1999. See NIHCM REPORT, supra, at ii.

It bears emphasis, however, many of the new drugs introduced in the 1990 s were not breakthrough drugs - that is, new drugs whose marginal benefit is significant as compared to existing alternatives. The promise of genomics is that, in the future, a larger percentage of new drugs will actually be breakthrough drugs. See William Haseltine, The Promise of Genomics, in CONVERGENCE, ERnst \& YOUNG's BIOTECHNOLOGY INDUSTRY REPORT, MILlENNIUM EDITION 8 (2000), available at http://www.ey.com/global/gcr.nsf/US/Library-Health_Care-Ernst_\&_Young_LLP (last visited Feb. 27, 2001) (noting that "[o]ne important promise of genomics ... is that it may help alleviate the existing pharmaceutical industry's shortage of new blockbuster products and expand the long-term medical 
particularly problematic for the elderly, who are the prime users of prescription drugs, ${ }^{10}$ yet lack prescription drug coverage under Medicare (a program developed when prescription drugs had only a limited role in the arsenal of health care interventions).

In one sense, the debate over access to prescription drug interventions that emerge from genomics is simply a subset of the general health care redistribution debate. Thus, a person who favors a public guarantee of basic health care,$^{11}$ would design the guarantee to include prescription drug interventions that provide significant benefit relative to their cost. ${ }^{12}$ But there is an important difference between prescription drug economics and the economics of health care more generally. Unlike health care economics generally, prescription drug economics is profoundly shaped by intellectual property rights, primarily patent rights. ${ }^{13}$ Such rights can, at least in some circumstances and to some extent, convey monopoly power. $^{14}$ Moreover, because standard economic theory predicts that a

horizon"). In order for this promise to be realized, however, innovation will need to be channeled in a cost-effective direction through the explicit use of cost-benefit tradeoffs on the demand side. See infra notes $142-58$ and accompanying text.

10. Eighty-five percent of Medicare beneficiaries use at least one prescription drug annually. NIHCM REPORT, supra note 9 , at 1.

11. Legal scholars, ethicists, and policy analysts from across the ideological spectrum support the idea of redistribution to achieve universal access to basic health care. E.g., NORMAN DANIELS, JUST HEALTH CARE 36-58 (1985) (arguing that society must provide adequate health care services to its citizens in order to secure for them "normal opportunity range" and hence equality of opportunity); Allen E. Buchanan, The Right to a Decent Minimum of Health Care, 13 PHIL. \& PUB. AfF. 55-78 (1984) (arguing that alleviating the misery caused by lack of adequate health care is an obligation of beneficence that can, and should, be enforced through redistribution); see also Arti K. Rai, Rationing Through Choice: A New Approach to Cost-Effectiveness Analysis in Health Care, 72 IND. L.J. 1015, 1019-20 \& n.21 (1997) (collecting authorities who argue for redistribution of basic health care and an argument in favor of cost-effectiveness as a rationing choice). The devil lies in the details, however, as commentators differ vigorously over what types of services should be included in a basic care package. See Rai, supra, at 1022-30 (discussing problems with various approaches to defining basic care). Although a full discussion of the issue is beyond the scope of this article, I do suggest that medical costeffectiveness analysis is a valuable approach that could help delineate the contours of basic care. See infra notes 142-43 and accompanying text. For an argument in favor of cost-effectiveness as a rationing choice, see Rai, supra, at 1019-20.

12. As discussed further below, determinations of what interventions provide significant benefit relative to their cost are generally made through the use of medical cost-effectiveness analysis. See infra notes 142-43 and accompanying text.

13. One might suppose that because health care economics is driven by technology, see generally Joseph P. Newhouse, An Iconoclastic View of Health Care Cost Containment, HEALTH AFF., Supp. 1993 , at 153, patent rights might play a large role in health care economics more generally. However, Congress has determined that patents on medical or surgical procedures cannot be enforced. See 35 U.S.C. $\S 287$ (c)(1) (Supp. IV 1998). As for patents on medical instruments, these do contribute to health care costs. However, patented medical instrumentation generally represents only one component of the cost for any given medical intervention.

14. The precise nature of the drug manufacturer's monopoly power (if any) will depend on the scope of the patent, the possible availability of substitutes, the price sensitivity of consumers, and the extent of price discrimination through insurance. Because drug consumers who are insured are priceinsensitive, they typically do not engage in significant substitution. Thus the manufacturer of a patented drug may continue to enjoy significant power over price and output even when drugs similar to the patented drug (so-called me-too drugs) emerge. As discussed further below, see infra notes 144-50 and accompanying text, me-too drugs tend to emerge one to six years after the innovator drug is marketed. See CONG. BUdget OfFICE, How INCREASEd COMPETITION FROM GENERIC DRUGS HaS 
profit-maximizing producer with monopoly power will charge more and produce less than a producer in a competitive market, ${ }^{15}$ it should come as no surprise that patented prescription drugs - unlike most health care interventions - are often sold in limited quantities at supracompetitive prices. $^{16}$

In economists' terms, intellectual property rights trade a decrease in static efficiency, in the form of decreased output and higher prices, for an increase in dynamic efficiency, in the form of higher profits, which can lead to greater innovation. ${ }^{17}$ Notably, however, not all of the decrease in consumer surplus is transferred to the producer in the form of higher profits. Rather, because the producer's supracompetitive price typically excludes at least some individuals who would be willing to pay a price above marginal cost, a deadweight loss results. ${ }^{18}$ Thus, stimulating innovation through intellectual property rights inevitably raises diffirult questions regarding cost and access. Moreover, when one is discussing health care products, these questions have a particularly compelling moral basis. $^{19}$

The issue of how to balance prescription drug innovation with cost and access has been addressed primarily by patent law scholars. ${ }^{20}$ How-

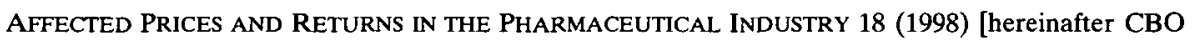
REPORT].

15. See Hal VARIan, INTERmediate ECONOMics 420-24 (5th ed. 1999). Unlike the competitive producer that produces to the point where price equals marginal cost, the monopolistic producer operates only at prices well above marginal cost. See id. at 420 . This is particularly true in industries like the prescription drug industry where the marginal costs of production are small.

16. Notably, however, although the manufacturer of a patented drug will typically charge a supracompetitive price, this price will not be the same for all consumers. To the contrary, drug manufacturers generally engage in price discrimination based upon the bargaining power of the purchaser. See infra notes $68-71$ and accompanying text.

17. In this paper, I use the term "innovation" to refer both to invention and to the development/commercialization of invention. The traditional justification for intellectual property rights has been that they promote the initial invention step. E.g., Sony Corp. v. Universal City Studios, 404 U.S. 417,429 (1984) (observing that intellectual property rights are "intended to motivate the creative activity of authors and inventors by the provision of a special reward"). Scholars have also emphasized that property rights promote development by ensuring that the rights holder captures the full investment it makes in developing the invention. See generally Edmund Kitch, Nature and Function of the Patent System, 20 J.L. \& ECON. 265 (1977). The case for promoting development through patent rights is, however, complicated by the reality that in some situations property rights in upstream research may actually impede rather than promote development. See infra notes 92-103 and accompanying text.

18. See VARIAN, supra note 15 , at $422-24$. Deadweight loss could be eliminated if the manufacturer were able to engage in perfect price discrimination. Although perfect price discrimination is virtually impossible in real world markets, the imperfect price discrimination practiced by drug companies does reduce deadweight loss. See infra note 126 and accompanying text.

19. Cf. William M. Sage, Funding Faimess: Public Investment, Proprietary Rights and Access to Health Care Technology, 82 VA. L. REV. 1737, 1741-42 (1996).

[An] obvious side-effect of patent monopolies - like other monopolies - is to increase price and decrease output. As a result, patented inventions may not be affordable to those who need them.

If equity is a concern in the provision of health care services, awarding patents, especially for breakthrough therapies, tends in the opposite direction.

20. E.g., Robert C. Guell \& Marvin Fischbaum, Toward Allocative Efficiency in the Prescription Drug Industry, MilBanK Q., June 22, 1995, available at 1995 WL 12381765; F.M. Scherer, Pricing, Profits, and Technological Progress in the Pharmaceutical Industry, 7 J. ECON. PERSP. 97 (1993); Mi- 
ever, these scholars have not addressed the potential impact of genomics on drug development. Moreover, in discussing the tension between innovation and cost/access, patent law scholars have tended to focus almost exclusively on drug production, thereby ignoring the institutional realities of health care consumption. Thus, for example, the growing number of commentators who advocate publicly financed buyouts of important pharmaceutical patents as a means of eliminating deadweight loss ${ }^{21}$ ignore the demand-side reality that for the most part, individual consumers do not purchase individual drugs directly at the time they need them. Rather, they enroll ex ante in an insurance plan that may or may not reflect their price-sensitivity with respect to any particular drug. As a consequence, it is often more difficult than usual to ascertain buyout price. On the other hand, the favorable price discrimination that insurance companies secure for their enrollees itself reduces deadweight loss, by securing access for individuals who could not afford the drug at the ordinary monopoly price. Indeed, subsidies directed at providing insurance for the uninsured could eliminate deadweight loss by giving all individuals the benefit of this price discrimination. Moreover, as contrasted with buyouts, which would subsidize those who could already afford access at the monopoly price, subsidies specifically directed at providing insurance to the uninsured would require a relatively small commitment of tax revenue. $^{22}$

For their part, health care scholars have rarely addressed the incentive structure that produces pharmaceutical innovation. Indeed, rather than viewing innovation as a positive activity, they have tended to view it negatively, as creating the higher health care costs that result in decreased access. ${ }^{23}$ Like patent scholars, however, health care commentators have not considered the impact that genomics may have on the economics of drug development. More importantly, they have not focused sufficiently on the fact that the health care cost problem stems not from innovation itself but from the inability of health care markets to make

chael Kremer, Patent Buyouts: A Mechanism for Encouraging Innovation (Nat'l Bureau of Econ. Research, Working Paper No. 6304; 1997); see also CBO REPORT, supra note 14.

21. E.g., Guell \& Fischbaum, supra note 20; Kremer, supra note 20; see also Steven Shavell \& Tanguy van Ypersele, Rewards vs. Intellectual Property Rights (Nat'l Bureau of Econ. Research, Working Paper No. 6956, 1999). Only Guell and Fischbaum would mandate such buyouts.

22. More populist proposals to increase access through mechanisms such as reasonable pricing requirements for pharmaceuticals, particularly pharmaceuticals based on publicly funded research, also suffer from the difficulty that they subsidize access for those who can already afford such access. Calls for reasonable pricing requirements also presume that the government will be able to regulate prices in a manner that provides adequate incentives for innovation.

23. Thus, for example, health law scholars often note that although the U.S. spends well over a trillion dollars on health care-far more per capita than any other industrialized nationapproximately one-sixth of the population remains uninsured. E.g., William M. Sage, Regulating Through Information: Disclosure Laws and American HealthCare, 99 COLUM. L. REV. 1701, 1702 (1999); see also Einer Elhauge, The Limited Regulatory Potential of Medical Technology Assessment, 82 VA. L. REv. 1525, 1525 (1996) (noting that "[e]xpensive new technology is routinely blamed for our health care cost explosion"). 
proper cost-benefit trade-offs with respect to innovation. As a consequence, pharmaceutical innovation has, for the last decade or so, been directed toward drugs that provide relatively low marginal benefit relative to their marginal cost. ${ }^{24}$

In this paper, I advance a theory of pharmaceutical development and allocation that attempts to address these gaps in patent and health law scholarship. I argue that genomics has the potential to make reform that increases access to prescription drugs not only more necessary as a matter of equity but also more feasible as a matter of innovation policy. The argument on the innovation, or production, side runs as follows. So long as patent rights in upstream genomics research do not create transaction cost bottlenecks, genomics is likely to yield at least some reduction in drug research and development costs. If these cost reductions are realized, it should be possible to scale back certain features of the pharmaceutical patent regime that cause patent protection for pharmaceuticals to be significantly stronger than patent protection for other innovation. ${ }^{25}$ On the consumption side, genomics should make drug therapy even more important in treating illness. This reality, coupled with empirical data revealing that cost and access problems are particularly severe for those individuals who are not able to secure favorable price discrimination through insurance, militates in favor of government subsidies for such insurance. These subsidies should, however, be linked to insurance regulation that works to channel innovation in a cost-effective direction by requiring coverage of drugs that provide significant benefit relative to their cost.

Part I of the article describes the various intellectual property protections that attach to prescription drugs and analyzes the role these protections play in drug development and allocation. Part II argues that, so long as upstream patent rights do not play an obstructionist role, genomics has the potential to reduce $R \& D$ expenditures and increase the centrality of drug therapy to health care delivery. Part III specifies some intellectual property (i.e., production side) reforms that would take advantage of future savings that may be delivered by genomics, so as to reduce drug costs and improve access without impairing innovation incentives. Part IV then suggests some health policy, or consumption side, reforms that would capture the health benefits of genomics-based drugs

24. See discussion infra note 143 and accompanying text.

25. Because of certain, largely unintended, consequences of the Hatch-Waxman Act, the pharmaceutical industry enjoys significantly greater patent protection than other industries. Notably, in the industry most directly subject to Moore's law - the semiconductor industry itself - patent rights have historically played a smaller role than in the pharmaceutical industry. E.g., Robert P. Merges, Contracting Into Liability Rules: Intellectual Property Rights and Collective Organizations, 84 CAL. L. REV. 1293, 1353 (1996) (discussing the fact that semiconductor patents are generally not enforced but instead are used as bargaining chips); see also BRONWYN HALL \& ROSEMARIE HAM, THE PATENT PARADOX RevistTed: Determinants OF PATENTING IN THE U.S. SEMICONDUCTOR INDUSTRY (Nat'l Bureau of Econ. Research, Working Paper No. W7062, 1999) (noting that, despite industry increase in semiconductor patenting, firms do not rely heavily on patents). 
by providing insurance for drugs that produced significant benefit relative to their cost.

\section{THE ROLE OF INTELLECTUAL PROPERTY IN DRUG INNOVATION AND ALLOCATION}

\section{A. Stimulating Innovation Through Intellectual Property Rights}

As every student of intellectual property knows, intellectual property rights provide a financial incentive for researchers to devote time and energy to making and developing socially useful inventions that are expensive to produce but quite inexpensive to copy. ${ }^{26}$ Prescription drugs are a quintessential example of such invention. Even after a particular compound has been identified as a promising therapeutic possibility - a process that can, in and of itself, take years - it has to go through preclinical testing on laboratory animals, the filing of a new drug application (NDA) with the Food and Drug Administration (FDA), three stages of clinical/human testing ${ }^{27}$ and a final FDA review. Only a very small percentage of drug candidates succeeds in passing through each of these stages so as to make it to market..$^{28}$ As a consequence, the process of discovering and developing a drug typically takes eleven or twelve years and can cost hundreds of millions of dollars per successful drug that makes it to market. ${ }^{29}$ Thus, the standard argument from the biotechnol-

26. Numerous economists have discussed this "public good" justification for intellectual property rights. E.g., Subcomm. ON Patents, Trademarks, and Copyright of the Senate Comm. ON the Judiciary, 85Th Cong., An Economic Review of the Patent System (Comm. Print 1958); FREDERIC M. SCHERER, INDUSTRIAL MARKET STRUCTURE AND ECONOMIC PERFORMANCE 444 (2d ed. 1980). Moreover, intellectual property case law, particularly in the patent area, has specifically recognized this utilitarian goal. E.g., Graham v. John Deere Co., 383 U.S. 1, 9 (1966) ("The patent monopoly was not designed to secure to the inventor his natural right in his discoveries. Rather, it was a reward, an inducement, to bring forth new knowledge.").

27. In the three stages of human testing, the compound is first tested on a small group (less than 100 ) of healthy volunteers to determine toxicity and a safe dosage range (Phase I trial). It is then tested for both safety and efficacy on a larger group (50-200) of human subjects who have the disease that the drug is supposed to treat (Phase II trial). Finally, the drug is tested on several thousand patients to verify effectiveness, determine the optimal dosage, and continue the safety evaluation (Phase III trial). See Joseph A. DiMasi et al., Cost of Innovation in the Pharmaceutical Industry, $10 \mathrm{~J}$. HEALTH ECON. 107, 110 (1991).

28. Only ten percent of compounds tested pass the preclinical stage. Of those compounds that make it to the human testing stage, more than eighty percent fail at that stage. See Michael Malinowski \& Maureen O'Rourke, A False Start? The Impact of Federal Policy on the Genotechnology Industry, 13 YALE J. ON REG. 163, 206-08 (1996).

29. These figures are drawn from several studies, including OfFiCE OF TECH. AssesSMENT, Pharmaceutical R\&D: Costs, Risks and Rewards (1993); Henry G. Grabowski \& John M. Vernon, Returns to $R \& D$ on New Drug Introductions in the 1980s, 13 J. HEALTH ECON. 383 (1994); DiMasi et al., supra note 27, at 125-27. Approximately two to three years are spent in the preclinical stages and eight to nine years in the clinical and final review stages. Moreover, although FDA reform legislation in the form of the Prescription Drug User Fee Act of 1992 (PDUFA) has shortened the average time spent in the final FDA review from thirty months to less than fifteen months, this streamlining has, at least until recently, been counterbalanced by a longer clinical testing period. See CBO REPORT, supra note 14, ch. 3, at 5-6. The FDA Modernization Act of 1997 aims to reduce clinical testing time by encouraging greater cooperation between the FDA and drug manufacturers. Indeed, 
ogy and pharmaceutical sectors - that intellectual property protection and the supracompetitive pricing that follows from such protection are necessary to recover the costs of a risky and expensive research and development process - has merit. Absent such protection and pricing, fewer drugs would be developed. ${ }^{30}$

Intellectual property law has been quite sensitive to the research and development hurdles faced by drug manufacturers. Indeed, a highly specialized system of patent protection has developed to foster pharmaceutical innovation. Thus, for example, drugs are accorded not only the ordinary twenty-year term of patent protection applicable to all invention $^{31}$ but also a significant number of special protections under the Drug Price Competition and Restoration Act of 1984 (Hatch-Waxman Act) ${ }^{32}$ Certain protections available under the Hatch-Waxman Act are intended to compensate drug manufacturers for the reduction in marketing exclusivity that results from the FDA's testing and approval process. This reduction occurs because drug manufacturers typically file patent applications before their drugs enter the clinical testing stages, ${ }^{33}$ thereby triggering the start of the twenty-year patent term. The time spent in the clinical testing and final review stages thus reduces the period of marketing exclusivity. The Hatch-Waxman Act compensates for this reduction by allowing drug manufacturers to extend their patent term by the sum of two periods of time: the time taken by the final FDA review and half

some recent data suggest that clinical testing times are beginning to decline. For example, during the period from 1996 to 1998, the average clinical testing time was 5.9 years. This represents an eighteen percent drop from the 1993-95 period, when the average clinical testing time was 7.2 years. See Tufts Center for the Study of Drug Development, Tufts CSDD Impact Report, available at http://www.tufts.edu/med/research/csdd/imprpt.html (last visited Feb. 27, 2001) (on file with the University of Illinois Law Review). Although this recent data may be anomalous, it is likely that genomics will produce a sustained reduction in the clinical testing period.

30. Cf. Richard E. Levin et al., Appropriating the Returns from Industrial Research \& Development, 3 BROOKINGS PAPER ON ECON. ACTIVITY 783-820 (1987) (indicating that the significance of patents varies by industry and that patents are particularly important in the pharmaceutical industry because of the costly development process).

31. In 1994, Congress passed the Uruguay Round Agreements Act (URAA), Pub. L. No. 103465, 108 Stat. 4809 (1994) (codified at 19 U.S.C. $\$ 3501$ (Supp. II 1996)), which amended the patent law so as to prescribe a twenty-year term that begins to run at the time of patent application. Under previous law, the patent term had been seventeen years, but the term did not begin to run until the Patent and Trademark Office (PTO) had granted the patent. Because the PTO application process generally takes two to three years, the amended twenty-year term provides roughly the same level of protection as the previous seventeen-year term. The URAA, which was intended to harmonize U.S. patent law with the patent law of most countries, also provides that any drug with a patent in effect as of June 8 , 1995 , or any patent application pending at that time, is entitled to receive the term of twenty years from time of filing, or seventeen years from time of grant, whichever is longer.

32. Pub. L. No. 98-417, 98 Stat. 1585 (codified as amended throughout 21 U.S.C. (1994)). This Act was sponsored by Representative Henry Waxman and Senator Orrin Hatch and is therefore often referred to as the Hatch-Waxman Act.

33. See Alfred Engelberg, Special Provisions for Pharmaceuticals: Have They Outlived Their Usefulness, 39 IDEA 389,393 (1999) (noting that it is common practice to file patent applications based upon a showing of utility in laboratory animals because waiting might result in the information becoming generally known and therefore unpatentable in the future). 
the time spent in clinical testing after the patent is granted. ${ }^{34}$ In recent years, most new drugs have received extensions that result in fourteen years of patent protection post-FDA approval, the maximum time allowed if the manufacturer avails itself of Hatch-Waxman protections. ${ }^{35}$ Indeed, many drugs enjoy some level of patent protection for well more than fourteen years. Drug manufacturers obtain this heightened protection by strategically seeking additional patents on a particular drug several years before the basic patent that has received the Hatch-Waxman extension is set to expire. ${ }^{36}$ Although these additional patents are often somewhat marginal in that they claim unapproved indications for the drug, specific drug formulations, or even tablet shape,${ }^{37}$ they can succeed in delaying generic competition. Such delay results because, as discussed further below, ${ }^{38}$ the Hatch-Waxman Act contains provisions that require courts to give brand-name drug manufacturers an automatic thirtymonth injunction against generic competition in response to claims that any patent, no matter how marginal, is being infringed. ${ }^{39}$

As a counterbalance to its patent term extensions for brand-name drugs, Hatch-Waxman promotes generic competition by streamlining the FDA approval process for generic drugs ${ }^{40}$ and by allowing generic manufacturers to perform the testing necessary for FDA approval while the brand-name patents are in place (thereby allowing the generic competitor to come on the market as soon as the patents expire). ${ }^{41}$ However, some of Hatch-Waxman's generic competition provisions have in fact allowed brand-name manufacturers to extend substantively the term of their monopoly. For example, suppose a generic manufacturer believes that the relevant brand-name patents are either invalid or are not infringed by the generic. By filing a certification to that effect (commonly known as a "Paragraph IV" certification), the generic manufacturer can

34. See 35 U.S.C. $\$ 156$ (1994). Hatch-Waxman imposes a five-year cap on the extension term that can be granted.

35. See Engelberg, supra note 33, at $\mathbf{4 2 0}$ (citing analysis issued by the PTO).

36. See id. at 415, 420; Sherry Gay Stolberg \& Jeff Gerth, How Companies Stall Generics and Keep Themselves Healthy, N.Y. TimEs, July 23, 2000, at 1.

37. See Engelberg, supra note 33, at 415.

38. See infra note 44 and accompanying text.

39. As a consequence, the judicially created doctrine of double patenting that prohibits a party from obtaining an extension of exclusive rights through claims in a later patent that are not patentably distinct from claims in an earlier patent, see Eli Lilly \& Co. v. Barr Lab., Inc., 222 F.3d 973, 985 (Fed. Cir. 2000), applies with less force to pharmaceutical patents than to other sorts of patents.

40. Under Hatch-Waxman, generic drug manufacturers are permitted to file an Abbreviated New Drug Application (ANDA) that relies upon drug safety and efficacy data submitted to the FDA by the brand-name manufacturer in the context of seeking approval for the patented drug. In order to obtain FDA approval, the ANDA must simply demonstrate that the generic drug is "bioequivalent" to the patented drug. 21 U.S.C. $\$ 355(J)(2)$ (A)(iv) (1994).

41. Manufacturers of generic drugs cannot be sued under the patent statute for acts "reasonably related to seeking FDA approval to market a drug, provided that no commercial use of a patented invention occurs before the patent expires." 35 U.S.C. $\$ 271(\mathrm{e})(1)$. Prior to the Hatch-Waxman Act, the usual period between patent expiration and generic entry was about three to four years, yielding an effective exclusivity term of about twelve to thirteen years. See CBO REPORT, supra note 14, ch. 4, at 2 . 
seek FDA approval to market the generic prior to the patent's expiration date. ${ }^{42}$ But as soon as the generic manufacturer files a Paragraph IV certification, the patent owner may not only sue for patent infringement ${ }^{43}$ but also receive a thirty-month automatic stay of the generic's approval process pending court consideration of the suit. ${ }^{44}$ During this thirtymonth stay period, brand-name manufacturers often succeed in delaying generic competition further by entering into settlements that pay the generic manufacturer not to market its product until the relevant patents expire. ${ }^{45}$ Such settlements are particularly effective in delaying competition when they are made, as they generally are, ${ }^{46}$ with the first generic company to file a Paragraph IV certification seeking FDA approval. Because the Hatch-Waxman Act accords this first generic filer a 180-day period of marketing exclusivity, ${ }^{47}$ and because the 180 -day period is not triggered until the generic producer chooses to begin commercial marketing or until a court holds the brand-name patent invalid or not infringed ${ }^{48}$ a settlement with the first generic applicant can delay any generic competition until 180 days after a subsequent generic applicant succeeds in a validity or noninfringement challenge.

Thus, for example, in a recent case investigated by the Federal Trade Commission (FTC), Abbott Laboratories entered into an agreement with Geneva, a generic competitor, that paid the generic company $\$ 4.5$ million per month to keep its version of Hytrin (a drug for treating hypertension and benign prostatic hyperplasia) off the U.S. market. ${ }^{49}$ Geneva also agreed not to transfer or assign its 180-day exclusivity right. ${ }^{50}$ Because Abbott estimated that generic entry would cost it several hundred million dollars a year in profits, it was more than willing to

42. See 21 U.S.C. $\$ 355(\mathrm{j})(2)(\mathrm{A})(\mathrm{vii})(\mathrm{IV})$ (providing that generic drug manufacturer can apply for FDA approval by certifying that the brand name patent "is invalid or will not be infringed by the manufacture, use, or sale of the new drug for which the application is submitted"). The generic drug manufacturer can also apply for FDA approval by certifying that the brand name patent has expired or by providing the date on which the patent will expire. See id. $\$ 355(\mathrm{j})(2)(\mathrm{A})(\mathrm{vii})(\mathrm{II})-(\mathrm{III})$.

43. See id. \&355(j)(5)(B)(iii) (providing patent owner automatic cause of action for patent infringement when generic manufacturer certifies that patent is invalid or not infringed).

44. See id.

45. See Engelberg, supra note 33, at 416-17; Stolberg \& Gerth, supra note 36 (discussing various agreements of this type). Even if they do not fully settle the case, brand-name manufacturers may be able to pay the generic manufacturer not to market its drug even after the thirty-month automatic stay period has expired. E.g., In re Cardizem CD Antitrust Litig., 105 F. Supp. 2 d 618 (E.D. Mich. 2000) (antitrust case challenging one prominent agreement between Hoechst Marion Roussel, Inc. (HMRI), the manufacturer of the brand-name prescription heart drug Cardizem, and Andrx, the manufacturer of the generic bioequivalent). Under the HMRV/Andrx agreement, HMRI was obligated to start making quarterly payments of $\$ 10$ million dollars to Andrx after the thirty-month automatic stay had expired. The payments were to end after the HMRI/Andrx litigation, including all appeals, was finally over. See id. at 632.

46. See sources cited in supra note 45

47. See 21 U.S.C. \& $355(\mathrm{j})(5)$ (B)(iv).

48. See id.

49. Geneva Pharmaceuticals, Inc. \& Abbott Laboratories, Analysis to Aid Public Comment, at http://www.ftc.gov/os/2000/03/genevaabbottanalysis.htm (visited Feb. 21, 2001).

50. See id. 
pay $\$ 4.5$ million per month to Geneva. For its part, Geneva profited handsomely from the settlement because it would have netted less than a third of the $\$ 4.5$ million sum if it had actually sold its generic product. ${ }^{51}$ The Abbott-Geneva agreement succeeded in keeping any competitor to Hytrin off the market for several years, until the FTC investigation and subsequent consent decree.

The preceding discussion demonstrates that the pharmaceutical industry is the beneficiary of a significant amount of special intellectual property protection under Hatch-Waxman. In addition, because the basic research that provides the basis for drug development is, more often than not, federally funded, ${ }^{52}$ the industry enjoys additional government support. Thus, for example, a 1995 study by researchers at the Massachusetts Institute of Technology determined that publicly funded research was a "critical contributor" to the discovery of almost all of the twenty-five most important drugs introduced between 1970 and $1995^{53}$ Similarly, a 1997 study commissioned by the National Science Foundation (NSF) found that fifty percent of the scientific research cited in drug and medicine patents was funded by the U.S. government. Only seventeen percent of the referenced research was funded by private industry. ${ }^{54}$ Moreover, various technology transfer statutes-principally the BayhDole Act of $1980^{55}$ and the Federal Technology Transfer Act of $1986^{56}$

51. See id.

52. In 1999 , total federal funding for health-related R\&D was $\$ 14.6$ billion. Ronald L. Meeks, President's FY 1999 Budget Keeps R\&D Spending at Last Year's Level When Adjusted for Inflation, NATIONAL SCIENCE FOUNDATION (Aug. 19, 1998), available at http:/www.nsf.nih.gov/sbe/srs/databrf/ sdb98329.htm. Domestic R\&D by pharmaceutical companies was $\$ 20.1$ billion.

53. See Iain Cockburn \& Rebecca Henderson, Public-Private Interaction in Pharmaceutical Research, 93 PROC. NAT'L ACAD. SCI. U.S.A. 12,725, 12,726 (1996). Cockburn and Henderson note that the development history of these twenty-five drugs offers some support for the traditional "linear" model of scientific discovery, which posits a considerable time lag before "basic" research focused on fundamental scientific principles can be translated into "applied" research that produces commercial products or processes. Based on this model, which underscores the difficulty of appropriating private returns from basic research, particularly in the short term, economists have long supported public funding for such research. E.g., Kenneth Arrow, in THE RATE AND DIRECTION OF INVENTION ACTIVITY 609 (Richard R. Nelson ed., 1962). Although the straightforward linear model is now widely rejected as too simplistic a description of a scientific process that is full of "leaps ahead, feedback loops, and sudden and unexpected lacunae," see Bruce Smith \& Claude Barfield, Contributions of Research and Technical Advance to the Economy, in TECHNOLOGY, R\&D AND THE ECONOMY 1 (Bruce Smith \& Claude Barfield eds., 1995), economists still stress that research that produces high rates of return that are difficult to appropriate privately should be publicly funded.

54. See Francis Narin et al., The Increasing Linkage Between U.S. Technology and Public Science, 26 RES. POL'Y 317, 318 (1997). The remaining thirty-three percent of the cited research was foreign science, much of it publicly funded. See id. Similarly, across all industries, seventy-three percent of the research cited by U.S. industry patents was publicly funded. See id. at 317.

55. Pub. L. No. 96-517, 94 Stat. 3015, 3019-28 (codified as amended at 35 U.S.C. $\$ \$ 200-212$ (1994)). As originally enacted, the Bayh-Dole Act applied only to small businesses and nonprofit organizations such as universities; in 1983, however, the Act was extended to apply to large businesses as well. See Rebecca S. Eisenberg, A Technology Policy Perspective on the NIH Gene Patenting Controversy, 55 U. PITT. L. REV. 633, 637 (1994).

56. Federal Technology Transfer Act of 1986, Pub. L. No. 99-502, 100 Stat. 1785-87 (codified as amended in scattered sections of 15 U.S.C. (1994)). The 1986 Act authorizes federal agencies to enter into cooperative research and development agreements (CRADAs) with private laboratories. Under 
permit the drug manufacturer to seek patent rights on this federally funded research. Thus, in cases involving federal funding, the drug manufacturer is given a very substantial subsidy, as it is allowed patent rights even though the federal funds presumably provide the requisite incentive to invent. ${ }^{57}$ Furthermore, even in cases where a third party, such as a university, owns intellectual property rights to the federally funded basic research, ${ }^{58}$ the drug manufacturer may be able to secure an exclusive license on the research by paying only a relatively nominal sum. ${ }^{59}$

The rationale for statutes that allow private industry to retain, or acquire, patent rights in publicly funded basic research is that exclusive rights will give industry an added incentive to engage in the expensive investment necessary to develop the research into a commercial invention. ${ }^{60}$ On this view, absent patent exclusivity, the likelihood of competition would deter development. In the case of pharmaceuticals, which themselves become the subject of patents at the clinical testing stage, the critical development stage for which property rights are needed is the period necessary to translate basic research into an invention that is ready for clinical testing. Although this argument has merit, ${ }^{61}$ there can be no

these agreements, the private laboratory owns any inventions made by its own employees. In addition, the government agrees in advance, subject to reservation of a royalty-free license, to assign patents on inventions made by federal employees to the collaborating private firm. See 15 U.S.C. $\$ 3710(\mathrm{c})$ (1994). The National Institutes of Health and the Department of Energy (two of the agencies primarily responsible for funding the human genome project) have entered in hundreds of CRADAs with private industry. See Malinowski \& O'Rourke, supra note 28, at 195.

57. See Rebecca S. Eisenberg, Public Research and Private Development: Patents and Technology Transfer in Government-Sponsored Research, 82 VA. L. REV. 1663, 1667 (1996) (noting that allowing private firms to hold exclusive rights in inventions that have been generated at public expense "contravenes the conventional wisdom that patent rights on existing inventions result in a net social loss ex post, a loss that we endure only to preserve ex ante incentives to make future patentable inventions"); see also Jeff Gerth \& Sheryl Gay Stolberg, Medicine Merchants: Birth of a Blockbuster, N.Y. TIMES, Apr. 23, 2000, $\$ 1$ (quoting drug development expert Louis Lasagna as saying, "NIH-supported research represents a subsidy to pharmaceutical development").

58. As noted supra note 55, the Bayh-Dole Act authorizes not only private industry but also nonprofit organizations such as universities to retain patent rights in the results of the their federally funded research.

59. To the extent that the manufacturer ends up paying the university a substantial sum of money, e.g., Gerth \& Stolberg, supra note 57, (noting that Columbia University receives $\$ 20$ million in royalties per year for a single glaucoma drug), much of the benefit of the subsidy goes to the university. A full discussion of whether university research is best funded directly or at least in part through licensing revenues is beyond the scope of this article. However, it bears mention that the increased role of funding through licensing revenues puts pressure on university researchers to concentrate on projects that may yield immediate commercial benefit.

60. Thus, for example, the House report that accompanied the Bayh-Dole Act emphasized the importance of patent rights for attracting the risk capital necessary for development. See H.R. REP. No. 96-1307, pt. 1, at 3 (1980). The Bayh-Dole Act's emphasis on development is echoed in the writing of some prominent academic commentators, who argue that the grant of intellectual property rights, like the grant of property rights generally, is necessary for development. See generally Kitch, supra note 17.

61. As discussed in part III, arguments focused on incentivizing preclinical development have less force as the expenditure and cost associated with such development goes down. Moreover, patent rights on early stage research may actually hinder development, by creating an "anticommons" of property rights that are difficult to aggregate usefully. See infra note 87. 
doubt that industry is the beneficiary of significant, publicly financed protection.

The elaborate structure of intellectual property protection discussed above gives the drug manufacturer the monopolistic or quasimonopolistic power necessary to charge supracompetitive prices. In what follows, I examine how the power to charge supracompetitive prices actually affects pharmaceutical pricing and access.

\section{B. Effects on Pricing and Access}

The available empirical data indicate that access problems are particularly acute for individuals who are not insured for the cost of prescription drugs. Thus, for example, a 1997 survey by the National Center for Health Statistics (NCHS) found that individuals without insurance were about five times more likely to report not getting needed prescriptions than individuals with insurance. ${ }^{62}$ Not surprisingly, the access problem was greatest for those uninsured individuals in poor health. Sixty percent of uninsured people in poor health reported not getting the medication that they needed. Similarly, within the population of Medicare beneficiaries, those who do not have insurance for prescription drugs are less likely to fill prescriptions than those with such insurance. Significantly, these differences cannot be explained by adverse selection into insurance by those in poor health; even controlling for health status, more prescriptions are filled by Medicare beneficiaries with drug coverage than beneficiaries without coverage. ${ }^{63}$

It is important to emphasize that this increased cost and reduced access is not simply a function of the lower out-of-pocket costs incurred by those who have insurance. Rather, it is also the case that individuals who pay cash for prescriptions actually pay more for any given prescription than do insurance plans. A recent report by the Department of Health and Human Services (HHS) found that, for the most commonly prescribed drugs, third-party payers - who are primarily pharmaceutical benefits managers for insurance plans - paid significantly less to pharmacies than did cash purchasers. In 1999, for example, the median difference between the median price paid by a cash purchaser and that paid by a third-party purchaser was $17.3 \% .{ }^{64}$ The actual discrepancy between individual and third-party payer costs is likely even greater, as the HHS report did not take into account the substantial rebates manufacturers give directly to third-party payers ${ }^{65}$ in order to induce these payers to

62. See HHS REPORT, supra note 9, at 80 . This five-fold difference would likely have been even larger had the survey eliminated from the insured pool individuals like Medicare beneficiaries who do not have insurance for prescription drugs.

63. See id. at $54-58$.

64. See id. at 127

65. See id. at $127-28$. 
place the manufacturer's drug on the plan formulary. ${ }^{66}$ Although data on these rebates is highly confidential and therefore difficult to gather, industry representatives report that rebate savings can be as high as thirtyfive percent on selected drugs. ${ }^{67}$

As the HHS analysis demonstrates, insurance companies can extract steep discounts from both pharmacies and drug manufacturers. To some extent, the economic issues raised by such discounting are fairly straightforward-like suppliers in other industries, pharmacies practice price discrimination in favor of entities such as insurance companies that can buy in large quantities. The economics of manufacturer rebates is, however, slightly more complex. Because drugs (like many other patented products) are costly to create but exceedingly cheap to produce in mass quantities once created, there exists the possibility of even steeper discounts for high-volume purchasers. In other words, because the marginal cost of producing a drug is so low, the manufacturer of a patented drug can earn substantial profits even while it attracts high-volume buyers by offering prices well below its ordinary supracompetitive price. This type of price discrimination by volume is called second-degree price discrimination. ${ }^{68}$ To a limited extent, drug companies also engage in third-degree price discrimination, in which they charge different groups of purchasers different rates independent of volume purchased. Thus, for example, health maintenance plans with "closed" formularies (i.e., plans that cover only particular drugs) may be able to obtain lower prices than less restrictive plans. ${ }^{69}$

In theory, drug companies could practice "perfect" price discrimination, in which they obtained information about each individual's willingness to pay for a particular drug and then charged a different price to each individual based on this information. ${ }^{70}$ Indeed, given the negligible marginal costs of producing drugs, perfect price discrimination might afford even poor individuals who are uninsured the opportunity to purchase drugs. Perhaps needless to say, however, the administrative costs of gathering accurate willingness-to-pay information, and the difficulty of restricting resale among purchasers, render this option unfeasible. ${ }^{11}$ Thus, as a practical matter, only insured individuals receive the benefit of price discrimination.

66. A formulary is the list of drugs covered by the health plan.

67. See HHS REPORT, supra note 9, at 105.

68. See VARIAN, supra note 15 , at $434-44$.

69. See HHS REPORT, supra note 9, at 107.

70. Under perfect price discrimination, all consumer surplus goes to the producer. See VARIAN, supra note 15, at 435-36. To some extent, those who propose patent buyouts hope to achieve the same result that would be achieved through perfect price discrimination.

71. As a consequence, there are very few real-world examples of perfect price discrimination. See id. at 436. 


\section{Drug Development and Allocation in the Post-Genomics ERA}

\section{A. The Preclinical and Clinical Implications of Genomics}

The increasing integration of genomics into drug development has the potential to change the economic structure of drug development, primarily by reducing the time and money it takes to discover and develop drugs. Equally important, it is likely to change the structure of health care delivery, by increasing the number of diseases that can be addressed by drugs. In this section, I address the economic and health impact of genomics.

In many situations, genomics should reduce the preclinical research time necessary to identify the relevant molecular "target" for a given disease. Consider the situation of a researcher who is interested in a particular disease. She may be able to use expression profiling/DNA chip technology to identify the gene sequence that is overexpressed in the cells of persons with that disease. Having identified the relevant DNA sequence, she should then be able to use other bioinformatic techniques to determine, in relatively short order, the function of the protein encoded by the gene and whether this protein could be an appropriate target for drug development. She will be able to do so by inputting the human DNA into a database that looks for similarities, or homologies, between the human DNA and previously sequenced DNA segments (either human DNA or the DNA of other organisms). If a match or near match is found, the researcher will be able to make an educated guess as to the function of the protein and as to whether it will be an appropriate target. $^{72}$

An early real-world example of this approach emerged in 1993, when researchers at the Philadelphia-based pharmaceutical company SmithKline Beecham isolated the DNA that was expressed in the osteoclast cells of people with bone tumors. ${ }^{73}$ SmithKline Beecham contacted the biotechnology company Human Genome Sciences (HGS), which sequenced the DNA, and found that one gene in particular was overexpressed. ${ }^{74}$ HGS then used database homology techniques to determine that the overexpressed gene encoded one of a previously identified class of enzymes known as cathepsins. For SmithKline Beecham, the genomics approach yielded in a few weeks a promising drug target (a particular

72. E.g., Ken Howard, The Genomics Gold Rush, 283 SCI. AM. 59 (2000) (characterizing the "in silico" prediction of protein function as "[o]ne of the most basic operations in genomics" and noting that it will "not only yield[ ] leads for drug targets early in drug development but also weed[ ] out many targets that would have turned out to be dead ends").

73. Osteoclasts are cells that resorb bone tissue in the ordinary course of bone replenishment.

74. DNA arrays, which contain hundreds or even thousands of short DNA sequences to which the expressed material can bind, are used to determine which genes are expressed, or overexpressed. 
variant of the cathepsin enzyme) that standard laboratory experiments might not have produced for years. ${ }^{75}$

The search used by SmithKline Beecham and HGS in the cathepsin case proceeded from sequence to protein. But genomics can also be used to speed up analysis that proceeds from identified protein to gene sequence. Indeed, SmithKline itself has used computer databases for this purpose, perhaps most notably to find the long-sought gene for betasecretase, a protease associated with Alzheimer's disease that belongs to the family of aspartic proteases. By searching computer databases for DNA sequences that could code for aspartic proteases, SmithKline researchers were able to quickly find the relevant gene. In contrast, it took the biotechnology company Amgen over two years to find the gene using conventional techniques. ${ }^{76}$ Moreover, in the not-too-distant future, as new databases on protein structures and biochemical pathways become available, even searches for actual drugs - that is, the chemical compounds that bind to and have the desired effect on drug targets - may take place on computers. As matters currently stand, such searches are done in a traditional "wet" lab, where evaluations for activity, toxicity, and absorption can take years. ${ }^{77}$

To be sure, not all preclinical research based on genomics will proceed on this expedited basis. For example, the practice of identifying genes and gene families through large-scale mining of sequence databases does not, in and of itself, generate useful information about the connection between any given gene and disease process. Using this approach, finding the connection between gene and disease may be quite expensive and difficult. ${ }^{78}$ Nonetheless, on balance, reductions in preclinical research time and expense are likely at least in the long term, as firms become more familiar with genomics.

Efficiency payoffs may arise not only in the preclinical stages but also in the clinical/human testing stages. Currently, about eighty percent of drugs fail in the clinical testing stages ${ }^{79}$ because a certain percentage of the subject population either fails to respond to the drug or suffers severe

\footnotetext{
75. See Howard, supra note 72 , at 61.

76. See Chang, supra note 4, at D1.

77. See Howard, supra note 72 , at 61 . Indeed, even wet lab search time is being reduced through the use of ultra-high throughput screening instrumentation. Of course, the examples discussed in the text represent something of a best-case scenario, involving a disease that is associated with only one gene. By contrast, for the many important diseases that are polygenic in nature, gene and protein identification will not be as straightforward. Nonetheless, the efficiency gains yielded by computing power may be substantial even in the case of polygenic diseases.

78. See Allen D. Roses, Pharmacogenetics and the Practice of Medicine, 405 NATURE 857, 859 (2000) (observing that there may be "enormous economical costs associated with searching huge lists of genes for the 'right disease for the available gene"'). In addition, at least in certain cases, differential expression of a given gene in the cells of a patient with a particular disease may not be causally related to the disease but, rather, may simply be a consequence of the disease progression. $I d$. at 859 . In the latter case, the gene that is expressed differentially will not be a useful target for drug discovery.

79. See supra note 28 and accompanying text.
} 
adverse reactions. ${ }^{80}$ Failure at the so-called Phase III stage of clinical testing, which generally involves thousands of patients, can be particularly time-consuming and costly. In many of these cases of failure, the individuals who do not respond favorably have a complement of small genetic variations (known as single nucleotide polymorphisms, or SNPs) that renders their DNA different from that of the favorable responders. ${ }^{81}$ With genomics (specifically DNA arrays or chips, which can store thousands of DNA samples), the small, relatively inexpensive Phase II clinical trial stage could be used to determine which individuals had the SNP complement necessary for them to respond favorably to a particular drug. Only individuals with similarly favorable SNP complements would then be used in Phase III trials. Moreover, because of the absence of side effects, the requisite efficacy might be proven in a smaller cohort of Phase III patients than is currently the case. ${ }^{82}$ Smaller, faster, and more successful Phase III trials would reduce considerably the cost of drug development.

As with preclinical research, a caveat is in order. Obviously enough, the exclusion of certain individuals as candidates for a drug therapy means that the target market for that drug will be smaller. As a consequence, reductions in the cost and expense of clinical testing have to be balanced against the reality of smaller markets for particular drugs. Nonetheless, it is likely that in many, if not most, cases the combination of reduced preclinical and clinical testing times will outweigh reductions in the size of the target population. ${ }^{83}$

80. Problems with side effects are not confined to the clinical testing stage. As many as 100,000 people die every year from side effects and another two million fall ill. See Rick Weiss, The Promise of Precision Prescriptions, WASH. POST, June 24, 2000, at A1.

81. Not surprisingly, the relevant SNPs usually arise in genes that are responsible for drug metabolism. For example, as John Weinstein of the National Cancer Institute has noted, polymorphisms in the CYP2D6 locus affect the metabolism of a wide range of agents, including beta-blockers, antidepressants, antipsychotics, and opioids. See John Weinstein, Pharmacogenomics - Teaching Old Drugs New Tricks, 343 NEW ENGL. J. MED. 1408 (2000).

82. See id. (quoting CEO of Genaissance Pharmaceuticals as saying that because efficacy could be proven in cohorts of a few hundred patients, as compared to the thousands of patients used currently, genetic screening should change "the economics of drug development radically").

83. See id. at 1408 (noting that although pharmacogenomics has the potential disadvantage of dividing the market for a drug, it has the larger potential advantages of eliminating poor candidate drugs early in the development process and decreasing dramatically the size and expense of clinical trials). To be sure, segregation based on SNP complements would leave the issue of what to do with the unfavorable responders (or with favorable responders for that matter, if the number of favorable responders was sufficiently small that it would be unprofitable to develop the drug). The question of what to do with those who have relatively rare SNP complements is a subset of the larger question of how we should address rare diseases. It is fundamentally a question of distributive justice (albeit a question of distributive justice complicated by the fact that rare diseases and rare SNP complements are often inherited along racial and ethnic lines). Given that rare diseases cost more money per person to address than more common diseases (because the costs of developing a drug will be spread across fewer people), and that ordinary market forces will not produce such drugs for such diseases, how much should we as a society subsidize their production? Currently, rare diseases-defined as conditions that affect fewer than 200,000 patients in the U.S. or for which there is no "reasonable expectation that the cost of developing... [the] drug for such disease or condition will be recovered from sales in the United States of such drug," 21 U.S.C. $\$ 360 \mathrm{ee}(\mathrm{b})(2)$ (1994), are addressed by the 
Genomics should have a significant effect not only on drug development but also on clinical care. In the post-genomics era, it will be possible to address effectively many more common conditions, both acute and chronic, that have a genetic component. Furthermore, these diseases will be addressed more precisely than before. Genetic screening techniques of the sort discussed above should allow physicians to ensure that the drugs they provide to their patients will be efficacious and will not produce dangerous side effects. Currently, as a result of SNP-based variability in drug response, more than 100,000 individuals die every year and another two million are made seriously ill. ${ }^{84}$ Thus it will be more essential than ever that the basic package of health care services to which all individuals have access includes drugs, particularly drugs that provide significant health benefits relative to their costs. ${ }^{85}$

\section{B. Avoiding Transaction Cost Barriers to Development}

An important impediment to accelerated preclinical and clinical investigation might be created by the hundreds of thousands of patent applications that have been filed by certain firms on early-stage genomics research, such as gene fragments, SNPs, or protein structures of unknown function. ${ }^{86}$ As I have argued in previous writing, ${ }^{87}$ these patents are hardly necessary as an incentive for generating such low-cost research. ${ }^{88}$ Nonetheless, they could-depending on how issues of patent

Orphan Drug Act. Under the Act, the FDA assists orphan drug manufacturers in negotiating the administrative hurdles of the drug approval process. See 21 U.S.C. \& 360aa(a) (1994 \& Supp. III 1997). On occasion, it also provides funding for the clinical testing of orphan drugs. See id. For its part, the IRS provides tax credits for expenses related to orphan drug development. See 26 U.S.C. § 45C (Supp. III 1997). The Act's provision of a limited subsidy to those with rare diseases represents a rough compromise between deontological considerations and strictly utilitarian ones. Although a full discussion of the question is beyond the scope of this paper, any societal decision that is made with respect to those who have relatively rare SNP complements should similarly reflect a mix of such considerations. I discuss this issue more comprehensively in Arti K. Rai, Pharmacogenetic Interventions: (Yet) Another Challenge in Allocating Health Care, 19 SOCLAL PHILOSOPHY \& POLICY (forthcoming 2002).

84. See Weiss, supra note 80 , at A1.

85. Notably, because drugs will be prescribed only to those patients who have a high probability of benefit, the cost-effectiveness of any given drug is likely to be higher than is currently the case.

86. See Andrew Pollack, The Next Chapter in the Book of Life is Written in the Proteins, N.Y. TIMES, July 4, 2000, at D1 (discussing patent applications on protein structures); Lori Valigra, Genomics at Heart of Revolutions in Corporations, Global Economy, BIOTECHNOLOGY NEwSWATCH, Aug. 17, 1998 (discussing patent applications on gene sequences).

87. See Arti K. Rai, Regulating Scientific Research: Intellectual Property Rights and the Norms of Science, 94 Nw. L. REv. 77, 119 (1999); see also Michael A. Heller \& Rebecca S. Eisenberg, Can Patents Deter Innovation? The Anticommons in Biomedical Research, 280 SCIENCE 698 (1998).

88. In this regard, is important to distinguish between gene fragments, SNPs, and proteins of known function and those of unknown function. In order to determine the function of a gene fragment, SNP, or protein, the researcher has to make a significant research investment. One CEO of a bioinformatics company recently estimated that the cost of simply finding a gene fragment or SNP of unknown function is about one percent of the cost of determining its function. See Hugh Reinhoff, Presentation at UC Berkeley, Advanced Patent Law Institute (Nov. 10, 2000). Patent protection provides the necessary incentive to make the research investment in determining function. 
scope were interpreted ${ }^{89}$ - create a web of property rights that is very difficult for developers of pharmaceuticals or DNA chips to negotiate. ${ }^{90}$ If such rights were granted, a pharmaceutical company that was interested in developing a commercial treatment for a particular genetic disease might have to seek licenses from any entity that held patents on gene fragments (also known as expressed sequence tages, or ESTs) or SNPs found within the relevant gene. ${ }^{91}$ Similarly, the maker of a DNA chip that tested for hundreds, if not thousands, of different SNPs might have to seek licenses from a variety of different SNP patent owners.

Bargaining could occur ex ante, before the pharmaceutical company or chip maker had conducted any research, or ex post, after (for example) the pharmaceutical company had identified, and perhaps even patented, the relevant disease gene or genes. In either event, however, this bargaining would be conducted in a setting quite far removed from the Coasean ideal. ${ }^{92}$ In the ex ante case, there might be considerable uncertainty as to the value of the EST or SNP of unknown function, particularly if it was not clear whether the EST or SNP was found within a gene of interest. Alternatively, even if the pharmaceutical company knew that the EST or SNP was within a gene of interest, it might be reluctant to disclose that information lest the patent holder simply appropriate that information..$^{93}$ Ex post, we might be dealing with a bilateral monopoly situation in which the EST or SNP patent holder could block the use of a disease gene even though its research contribution was exceedingly small relative to that of the pharmaceutical company. ${ }^{94}$ In the latter situation, the EST or SNP patent holder might be tempted to act strategically, to charge not simply a supracompetitive price but, indeed, a price far in excess of its share of the cooperative surplus. ${ }^{95}$ Indeed, the director of re-

89. For a discussion of the PTO's evolving stance on patent scope issues, see infra notes 98-100.

90. See Rai, supra note 87, at 120-35; see also Heller \& Eisenberg, supra note 87; Clarisa Long, Proprietary Rights and Why Initial Allocations Matter, 49 EMORY L.J. 823 (2000).

91. See Rai, supra note 87 , at $125-28$.

92. See Guido Calabresi \& A. Douglas Melamed, Property Rules, Liability Rules, and Inalienability: One View of the Cathedral, 85 HARV. L. REV. 1089, 1094-95 (1972) (noting that the assumption of no transaction costs presupposes "both perfect knowledge and the absence of any impediments or costs of negotiating").

93. See Rai, supra note 87, at 126 (discussing problem of Arrow's information paradox). As discussed supra note 88, simply finding an EST or SNP represents about one percent of the work of determining its function.

94. See Rai, supra note 87, at 128.

95. See id.; see also Mark A. Lemley, The Economics of Improvement in Intellectual Property Law, 75 TEX. L. REV. 989, 1050-51 (1997); Robert Merges, Intellectual Property Rights and Bargaining Breakdown: The Case of Blocking Patents, 62 TENN. L. REV. 75, 81-82 (1994) (discussing particular problems caused by blocking patents when one patent holder has made a contribution that is very small relative to that of the other patent holder). Indeed, Suzanne Scotchmer has suggested that ordinary (noncollusive) licensing, whether done at the ex ante stage or the ex post stage, can never provide sufficient incentives for both the first innovator and follow-on innovators. See generally Suzanne Scotchmer, Standing on the Shoulders of Giants: Cumulative Research and the Patent Law, 5 J. ECON. PERSP. 29 (1991). It also bears mention that even if the initial patent holder were to charge only an "ordinary" supracompetitive price, this price would obviously be in excess of the amount that the pharmaceutical company would have to pay if the EST or SNP was not the subject of a patent. In 
search at one pharmaceutical company recently estimated that there were more than fifty proteins possibly involved in cancer on which the company was not working because agreements with upstream patent holders could not be concluded. ${ }^{96}$

Fortunately, it appears that the potential for such a research bottleneck may have been mitigated by various public-domain oriented strategies adopted by the participants in the publicly funded Human Genome Project, as well as by the pharmaceutical industry and certain DNA chip makers. The National Institute for Health's (NIS) National Human Genome Research Institute (NHGRI) and its associated university research laboratories have, from the outset, released all raw genome data within twenty-four hours, thereby thwarting the possibility of any intellectual property rights in such raw data. ${ }^{97}$ The NHGRI-led campaign against property rights in early-stage research has also been responsible in significant part for the Patent and Trademark Office's (PTO) new guidelines on utility, which indicate that gene fragments, SNPs, genes, and protein structures of unknown function lack utility under $\S 101$ of the patent statute and are therefore not patentable. ${ }^{98}$ These new guidelines will likely prove most useful in curbing the behavior of private biotechnology companies: even before the recent guidelines, most universities that conducted genomics research refrained from seeking patents on genetic information of unknown function. ${ }^{99}$ In addition, once again in response to pressure from the NHGRI and academic researchers, the PTO appears to be shifting from its view that patents on gene fragments give the patentee the power to block research on full genes, even genes that have been discovered and patented independent of any prior EST or SNP research. Training materials recently issued for PTO examiners suggest that patents on gene fragments will be quite narrow in scope and may not

other words, even "ordinary" supracompetitive pricing produces deadweight loss and deviation from social welfare. See Molly A. Holman \& Stephen R. Munzer, Intellectual Property Rights in Genes and Gene Fragments: A Registration Solution for Expressed Sequence Tags, 85 IowA L. REV. 735, 789 (2000) (making similar argument). It also adds unnecessarily to the $R \& D$ costs associated with drug development. These facts may provide further explanation for the readiness of pharmaceutical companies to conduct their own upstream research and place it in the public domain. More generally, it provides another justification for placing upstream research in the public domain.

96. See Andrew Pollack, Bristol-Myers and Athersys Make Deal on Gene Patents, N.Y. TIMEs, Jan. 8, 2000, at C2 (discussing comments by Peter Ringrose, chief scientific officer at Bristol-Myers).

97. See Eliot Marshall, Genome Researchers Take the Pledge: Data Sharing, 272 SCIENCE 477, 478 (1996) (discussing resolution by publicly funded genome researchers that "all human genomic DNA sequence information generated by centers funded for large-scale human sequencing should be freely available and in the public domain in order to encourage research and development"). Because of the public release, neither patents nor trade secret rights can be sought in the raw data.

98. See PTO Revised Interim Guidelines Training Material 50-53 (2000); see also Peter G. Gosselin \& Paul Jacobs, Patent Office Now at Heart of Gene Debate, L.A. TIMES, Feb. 7, 2000, at A1 (noting that the PTO guidelines respond to "drumbeat of concern" by NHGRI and university scientists).

99. See Rai, supra note 87 , at 112-13. 
have blocking power with respect to full genes. ${ }^{100}$ Finally, the NHGRI's partner in the human genome sequencing project, the Wellcome Institute, has been instrumental in organizing and funding a consortium of pharmaceutical companies that is putting information regarding SNPs into the public domain. ${ }^{101}$ Not only does this SNP information become available to researchers free of charge but the availability of the information can create prior art that defeats subsequent attempts to patent the information. ${ }^{102}$ The SNP consortium is an interesting public-private partnership that demonstrates the concern private developers have about upstream property rights creating impediments to development. A similar public-private initiative to sequence the mouse genome, and to release the results of that sequencing into the public domain, was recently announced by the NIH, several pharmaceutical companies, and the DNA chip maker Affymetrix. ${ }^{103}$

100. See U.S. Patent \& TRademark Office, Synopsis of Application of Written DESCRIPTION GUIDELINES 30-32, available at http://www.uspto.gov (visited Nov. 27, 2000). By contrast, in a 1998 statement, John Doll, the Director of Biotechnology Examination at the PTO, had announced that the PTO viewed the relationship between a gene fragment and a full gene as analogous to the relationship between a picture tube and a television set. Doll noted that "[t]he picture tube patent does not preclude someone else from obtaining a patent on a television set. However, the holder of the picture tube patent could sue the television set maker for patent infringement if they use the patented picture tube without obtaining a license." John Doll, The Patenting of DNA, 280 SCIENCE 689,690 (1998). The PTO's apparent shift from its 1998 position may also be based in part on its recognition that the ultimate arbiter of patentability, the Court of Appeals for the Federal Circuit, views biotechnology as a subset of chemistry and is thus unlikely to decide biotechnology cases by drawing upon analogies from mechanical cases. For discussions of the Federal Circuit's view of biotechnology, see, for example, Janice M. Mueller, The Evolving Application of the Written Description Requirement to Biotechnological Inventions, 13 BERKELEY TECH. L.J. 615 (1998); Arti K. Rai, Intellectual Property Rights in Biotechnology: Addressing New Technology, 34 WAKE FOREST L. REV. 827 (1999).

Some significant issues regarding DNA patentability remain unresolved, however. One such issue is whether the utility of a DNA sequence can be demonstrated through assertions of similarity, or homology, to DNA sequences of known function. Some scientists argue that findings of homology, which are typically made "in silico," through computerized searches of DNA databases, should not be sufficient to prove utility. Although the PTO has suggested that it is willing to find utility based on findings of homology, see Utility Examination Guidelines, 66 Fed. Reg. 1092, 1096-97 (Jan. 5, 2001), its position is not altogether clear. Another unresolved issue is whether DNA sequence information stored in chip form (as contrasted with sequence information stored in a DNA molecule) should be patentable. At least one patent application has been filed on such information. See Rebecca S. Eisenberg, Re-Examining the Role of Patents in Appropriating the Value of DNA Sequences, 49 EMORY L.J. 783,793 (2000) (discussing patent application on DNA sequence of $H$. influenzae, stored in computerreadable medium). Although the PTO's utility guidelines indicate that it will not grant such patents, see Utility Examination Guidelines, 66 Fed. Reg. at 1094 (arguing that, in and of itself, DNA sequence information is descriptive, hence not patentable), the Federal Circuit may disagree. A discussion of whether patents should be granted on DNA as pure information is beyond the scope of this paper. However, if such patents are granted, they might create a significant research bottleneck.

101. See Nicholas Wade, 10 Drug Makers Join in Drive to Find Diseases' Genetic Roots, N.Y. TiMES, Apr. 15, 1999, at A19.

102. E.g., Rai, supra note 87, at 149-50 (discussing SNP consortium and other efforts to place upstream genetic information in the public domain); Rebecca S. Eisenberg, The Promise and Perils of Strategic Publication to Create Prior Art: A Response to Professor Parchomovsky, $98 \mathrm{MICH}$. L. REV. $2358,2365-66$ (2000) (same).

103. The sequencing will be done at the Washington University in St. Louis, the Whitehead Institute at MIT, and the Sanger Centre (U.K.). See Public-Private Project to Deliver Mouse Genome in 6 Months, 290 SCIENCE 242 (2000). 


\section{PRODUCTION SIDE REFORMS}

As the previous sections have discussed, there is optimism in the biotechnology and pharmaceutical communities about the future savings that genomics may yield. Indeed, one drug policy analyst recently estimated that genomics has the potential to accelerate development in a manner that saves as much as thirty percent of current R\&D costs. ${ }^{104} \mathrm{Be}-$ fore these savings are actually realized, we should of course be wary of using genomics as a basis for changing the structure of patent protection for pharmaceuticals. Countless biotechnology investors can attest to the failed predictions that have been made by industry forecasters over the last two decades. Moreover, because patents on a number of key drugs are set to expire in the next few years, the pharmaceutical industry may face financial pressures in the immediate term. ${ }^{105}$ Relatedly, in the next few years, the learning curve associated with genomics will be quite high; thus efficiency gains will not be realized immediately.

Nonetheless, it is important to think prospectively. If sufficient reductions in $R \& D$ costs are realized, we should be able to proceed with reforms that align patent protection for pharmaceuticals more closely with patent protection for other innovation. One small-scale reform in this direction might target settlements between brand-name manufacturers and Paragraph IV generic challengers ${ }^{106}$ that delay the market entry of generic drugs. Although some of these settlements have recently become the subject of antitrust scrutiny by the FTC, ${ }^{107}$ a more proactive approach would involve altering the Hatch-Waxman provisions that foster such collusive behavior. Thus, for example, a requirement that a generic challenger forfeit marketing exclusivity upon settlement with the brandname manufacture ${ }^{108}$ (or failure to begin marketing within a defined period of time $)^{109}$ would reduce collusion incentives. If market exclusivity

104. See Robert McCarthy, Can Drug Industry Hold On Unil Pharmacogenomics Moves In?, Drug ToPICs, Apr. 17, 2000, at 27.

105. See David A. Balto \& James F. Mongoven, Antitrust Enforcement in Pharmaceutical Industry Mergers, 54 FOOD \& DRUG L.J. 255, 256 (1999) (discussing reasons for recent consolidation in the pharmaceutical industry).

106. For a discussion of these settlements, see supra notes 45-51 and accompanying text.

107. See supra notes 49-51 and accompanying text. The FTC has also announced plans to subpoena records from ninety pharmaceutical companies to investigate drug industry strategies that delay the entry of generic competition. See Jeff Gerth, Agency Plans to Study Drug Makers' Records to See Whether Deals Delay Generics, N.Y. TIMES, Oct. 12, 2000, at A16.

108. See Engelberg, supra note 33, at 416-17.

109. In this regard, proposed FDA regulations that establish a 180 -day trigger period during which the generic manufacturer must use or lose the 180-day period of exclusivity may be a sound idea. The trigger period is activated after the tentative approval of a subsequent generic applicant for the same drug product. Proposed Rules, Dep't of Health \& Human Servs., F.D.A., 64 Fed. Reg. 42,873, 42,874-75 (Aug. 6, 1999) (codified at 180-Day Generic Drug Exclusivity for Abbreviated New Drug Applications, 21 C.F.R. pt. 314). Similarly, the Greater Access to Affordable Pharmaceuticals Act (GAAP), a bill recently introduced by Senator John McCain and Charles Schumer, provides that the 180-day period of exclusivity should roll over to the next generic applicant if the first applicant fails to market in a timely fashion. See McCain Joins Schumer in Sponsoring Generic Drug Approval Acceleration Bill, HEALTH NEWS DAILY, Sept. 15, 2000. 
were not guaranteed to the first generic challenger, the brand-name manufacturer could not buy protection from all generic competition simply by settling with this challenger. Elimination of the thirty-month automatic stay of the generic approval process accorded to the brandname drug manufacturer when a Paragraph IV action is brought might also reduce the opportunity for collusion. Even more importantly, if courts were no longer required to grant a thirty-month automatic stay, and could actually examine the validity of patents allegedly infringed before issuing a preliminary injunction, pharmaceutical companies would have to convince a court that their patent had at least some potential merit. Such a requirement would no doubt dampen brand-name manufacturer enthusiasm for seeking patents that claim unapproved uses, specific formulations, tablet shape, and the like. ${ }^{110}$

To be sure, addressing collusive settlements and questionable patent applications represents a small-bore reform. Indeed, even independent of genomics, there may be reasons to consider this reform, particularly given the fact that the drafters of Hatch-Waxman probably did not intend to promote collusion and marginal patent applications. On the other hand, this combination of collusion and marginal patent applications could be seen as merely another way of extending patent life and hence promoting innovation. It may be unwise to change a system that has been working reasonably well absent evidence the costs of innovation have gone down. ${ }^{111}$

In any event, Hatch-Waxman reform is but one example of the type of reform that might align protection for pharmaceuticals more closely with the standard patent regime. If savings from genomics are realized, another possible reform might focus on the reduced need to provide federal subsidies for preclinical development, given that the costs of such development will have gone down. For example, we could have some percentage of the profit from drugs based on basic research subsidized by the federal government go to a fund that provided subsidies for patients without access to insurance for drugs. A percentage-of-profits approach would be less intrusive and burdensome to research and development than other options, such as the "reasonable pricing" requirement that the $\mathrm{NIH}$ imposed on products that emerged from CRADAs during the period from 1989 to $1995 .^{112}$ Unlike the reasonable pricing requirement,

110. For a discussion of such marginal patent applications, see supra note 37 and accompanying text.

111. A focus on specific legal change in response to specific market changes is particularly important because economic analysis has not yielded conclusive answers regarding the "optimal" patent term in any given industry. E.g., Richard Gilbert \& Carl Shapiro, Optimal Patent Length and Breadth, 21 RAND J. ECON. 106 (1990); Paul Klemperer, How Broad Should the Scope of Patent Protection Be?, 21 RAND J. ECON. 113 (1990) (discussing conditions under which optimal patent life might be very short or very long).

112. See Baruch Brody, Public Goods and Fair Prices: Balancing Technological Innovation with Social Well-Being, HASTINGS CENTER REP., Mar.-Apr. 1996, at 5, 5 (discussing NIH's 1995 decision to eliminate the reasonable pricing requirement). 
which was roundly criticized as an effort at price control that chilled industry-government cooperation and technology transfer, ${ }^{113}$ a percentageof-profits approach would make no effort to set prices. Rather, it would simply be one means of raising money to promote access to drug insurance. Moreover, unlike a reasonable pricing mandate, which would subsidize the large number of individuals who can already afford access to pharmaceuticals (through insurance or otherwise), a percentage-ofprofits regime could be used specifically to subsidize uninsured individuals. I discuss these subsidies further in the next section, which focuses on demand side reform. I first consider, however, pharmaceutical patent buyouts, which are perhaps the most prominent access-promoting measure offered by patent law scholars.

\section{DEMAND SIDE REForms: InCORPORATING HEALTH CARE INSTITUTIONS}

\section{A. The Limitations of Patent Buyouts}

In the last few years, a number of prominent patent law scholars and law-and-economics theorists have proposed patent buyouts as a mechanism for addressing the access limitations and deadweight losses created by patents, particularly pharmaceutical patents. ${ }^{114}$ The argument in favor of patent buyouts runs as follows. If patents on FDA-approved drugs are bought out by the federal government and placed in the public domain, multiple manufacturers will be able to manufacture and sell these drugs at competitive prices. Deadweight loss will be eliminated, and access will increase. One of the earliest such proposals, put forward by Robert Guell and Marvin Fischbaum, argues that the federal government should use its eminent domain power to "take" pharmaceutical patents and pay "just compensation." edge, but do not address, the possibility that fiscal pressures might lead the government to underestimate the profits figure, thereby deterring future investment in research.

In contrast with Guell and Fischbaum, a more recent proposal put forward by Michael Kremer would not mandate buyouts. As Kremer rightly points out, mandatory buyouts might "degenerate into a process through which the government could expropriate inventors." 116 Simi-

113. Based on this precedent (as well as more general arguments about the manner in which price controls can suppress innovation), few scholars continue to support price controls, even on pharmaceuticals that emerge from government-funded research. But see Peter S. Arno \& Michael H. Davis, Why Don't We Enforce Existing Drug Price Controls?: The Unrecognized and Unenforced Reasonable Pricing Requirements Imposed Upon Patents Deriving in Whole or in Part From Federally Funded Research, _ TUL. L. REV. (forthcoming 2001).

114. Two of the three major proposals focus primarily or exclusively on pharmaceutical patents. See Guell \& Fischbaum, supra note 20; Kremer, supra note 20.

115. See generally Guell \& Fischbaum, supra note 20.

116. Kremer, supra note 20 , at 4. 
larly, Steven Shavell and Tanguy van Ypersele stress the virtues of an optional buyout system. ${ }^{117}$ The major problem associated with patent buyouts is that of valuation. The threshold valuation question is whether the buyout should attempt to capture all social surplus created by the invention (which would include not only all consumer surplus but also any. positive externalities created by the spillover of ideas to other researchers) or simply the actual profits the monopolist would have made if the patent was in force. Kremer and Shavell/van Ypserele agree that in order for the buyout to encourage optimal innovation, the buyout price should approximate total social surplus - a figure significantly higher than the actual monopoly profits any patent owner would make.

On first examination, it might appear that rewarding drug companies with the full social surplus produced by their innovation would provide optimal incentives for such innovation. However, the greater the reward associated with patent rights, the greater the possibility of patent races that produce excessive or duplicative investment. ${ }^{118}$ So the argument in favor of a social surplus approach is hardly unimpeachable. Indeed, Shavell and van Ypersele admit that the magnitude of the reward they propose would be affected by a factor that "we did not study in our model: the race among potential innovators to be the first to innovate." 119

Even assuming arguendo that a social surplus approach is theoretically superior, the government must be able to measure the surplus. Both Shavell/van Ypersele and Kremer recognize the limits of centralized government investigation and thus attempt to harness private market information in their valuation mechanism. Under Shavell and van Ypersele's proposal, the government would obtain information about the total social value of an innovation by allowing actual sales of the product

117. See Shavell \& van Ypersele, supra note 21, at 7 (noting that the optional buyout/reward system "unambiguously dominates patent"). Shavell and van Ypersele do suggest that, under certain conditions, a mandatory reward system would be superior to the patent system. See id. at 8 . They appear to conclude, however, that since the government might act suboptimally, and give unduly conservative rewards, an optional reward system is preferable. See id. at 26.

118. See generally JEAn TIROLE, The ThEORY OF Industrial ORganization, ch. 10 (1988).

119. Shavell \& van Ypersele, supra note 21, at 23. Some commentators have suggested that patent race problems would be exacerbated by the mere fact of a patent buyout, irrespective of its magnitude. See F. Scott Kieff, Property Rights and Property Rules for Commercializing Inventions, 85 MinN. L. REV. 697, 711 (2000) (arguing that any buyout, no matter its magnitude, will exacerbate the race problem). In the context of pharmaceuticals, however, this view is mistaken. Buyout proposals contemplate purchasing drug patents after the drug has been patented and approved by the FDA. E.g., Kremer, supra note 20, at 38-44 (noting that FDA-approval process may give information on value of drug patent). A drug that has been patented and approved by the FDA is not a nascent invention that is likely to be the focus of significant further development. Thus, the role that property rights may play in guarding against rent-dissipating races to develop/improve nascent invention, see, e.g., Mark $\mathrm{F}$. Grady \& Jay I. Alexander, Patent Law and Rent Dissipation, 78 VA. L. REV. 305 (1992), and/or in stimulating development or improvement of nascent invention, see, e.g., Harold Demsetz, Toward a Theory of Property Rights, 57 AM. ECON. REV. 347 (1967), is not implicated; Edmund Kitch, Nature and Function of the Patent System, 20 J.L. \& ECON. 265 (1977). 
in a competitive market. ${ }^{120}$ In the case of many products, the Shavell/van Ypersele approach might be a clever one. Sales information would reveal important information about the shape of the demand curve. This information could be used to estimate total consumer surplus, the most important component of social surplus. However, in the context of pharmaceuticals, the Shavell/van Ypersele proposal has limitations. As contrasted with other goods, individuals do not generally purchase individual pharmaceuticals at the time they need them. Rather, they enroll ex ante in insurance plans that cover pharmaceuticals. These plans often do not differentiate their insurance product on the basis of the pharmaceutical products they offer. Even when plans do differentiate, it is at best a very rough differentiation (e.g., between plans with no drug coverage, plans with a closed formulary, and those with an open formulary). Virtually no insurance plan differentiates its product based on its coverage of a particular pharmaceutical. Thus it is difficult to discern the demand curve for a particular pharmaceutical from its sales. The Shavell/van Ypersele approach also raises some tricky questions of timing. If the government does not know its purchase price for an invention until after it starts selling the invention at a competitive price, the patent owner must decide whether or not to forsake the patent before it knows precisely what the government's purchase price will be. This timing difficulty could presumably be obviated by allowing the patent holder to retain its patent and then estimating the demand curve based on sales of the patented product. Such an approach would, however, produce deadweight loss. It might also allow the patent holder to manipulate the quantity sold for purposes of receiving a higher buyout price. Indeed, Shavell and van Ypersele note that the latter problem militates in favor of having a competitive market. ${ }^{121}$

A miscalculation of reward is also likely under the valuation method urged by Kremer. Kremer's method would estimate private value (i.e., actual monopoly profits) through the use of an auction. The government would then buy out the patent at a price based on the auction bid, increased by a multiplier that corresponded to the divergence between social value and private value. ${ }^{122}$ Although Kremer adopts a multiplier of two, he acknowledges that this is only a rough average taken from studies of innovation in a number of industries. ${ }^{23}$ In addi-

120. See Shavell \& van Ypersele, supra note 21, at 21-22 ("In past proposals for reward systems, payments based on sales and other information that government receives have sometimes been discussed. It would be a gross mistake to envision the reward as having to be premised on the government's estimate of valuation at the time an innovation is registered.").

121. See Shavell \& van Ypersele, supra note 21, at 19.

122. In order to provide auction participants with an incentive to reveal their valuation truthfully, some random subset of patents would in fact be sold to the highest bidder.

123. See Kremer, supra note 20 , at 10. 
tion, Kremer must develop an elaborate mechanism to ward off the possibility of collusion between the patent holder and auction bidders. ${ }^{124}$

Voluntary patent buyouts also present the problem of what to do with substitute invention. This is a particular problem in the pharmaceutical industry, where innovator drugs are, within a few years, followed by so-called me-too drugs that address the same illness but manage to do so without infringing the innovator patent. ${ }^{125}$ Suppose that the holder of a patent on innovator $\operatorname{drug} A$ rejects a buyout. By contrast, the developer of a me-too drug, $B$, accepts a buyout and $B$ is put in the public domain. Although $B$ would probably not be a perfect substitute for $A$, its availability at a competitive price might well undercut the value of the patent on $A$. Kremer acknowledges this problem and proposes a mechanism whereby the patent on $A$ could be auctioned along with the patent on $B$ when the patent on $B$ was auctioned. Given the pervasiveness of me-too pharmaceuticals, however, Kremer's proposed regime would effectively result in mandatory buyouts for many innovator patents.

Finally, it bears emphasis that pharmaceutical patent buyout proposals not only ignore the valuation difficulties created by the presence of insurance coverage, but they fail to capitalize on the favorable results - price discrimination and reduction in deadweight loss - that insurance coverage can produce. For those who have bargaining power by virtue of being insured, the pharmaceutical market is characterized by rampant price discrimination. The only individuals who do not receive the benefit of this price discrimination are those who lack bargaining power. In contrast with patent buyouts, which would subsidize not only those who lack access to pharmaceuticals but also those who comfortably have such access, subsidies directed at providing insurance for the uninsured would require a much smaller commitment of tax revenue. Thus, the efficiency losses that result from income taxation would be minimized. ${ }^{126}$

To be sure, eliminating deadweight loss through the very rough price discrimination secured by insurance company bargaining power does not allow drug companies to recover all of the social surplus created by their products. However, given the problems associated with patent races, and the presence of substantial public funding, it is by no means clear that we want to increase returns to pharmaceutical companies in

124. See id. at $38-44$.

125. See supra note 14.

126. See Joseph Bankman \& Thomas Griffith, Social Welfare and the Rate Structure: A New Look at Progressive Taxation, 75 CAL. L. REV. 1905, 1924 (1987) (referring to literature that estimates these efficiency losses as between $7.5 \%$ and $28.5 \%$ of tax revenue). See generally Douglas Frehman, Pricing Prozac: Why the Government Should Subsidize the Purchase of Patented Pharmaceuticals, 11 HARV. J.L. \& TECH. 123 (1997) (advocating subsidies to indigent individuals over buyouts because of reduced tax burden). Indeed, because the subsidies would only ensure access to a relatively parsimonious package of pharmaceuticals (in keeping with the idea that our social obligation is limited to covering a "decent minimum" of health care, see supra note 11 and accompanying text), the tax burden would be relatively small. 
the amounts contemplated by Kremer and Shavell/van Ypersele. In any event, increasing insurance coverage, particularly through the voucher method that I advocate in the next section, should increase returns beyond their current level.

\section{B. Securing Favorable Price Discrimination Through Insurance}

For the reasons discussed above, proposals that would subsidize the purchase of prescription drug insurance coverage, particularly for low and middle income uninsureds, make a great deal of sense. Subsidies for drug benefits will be particularly important in the era of genomics, as drugs received on an outpatient basis become an increasingly important part of basic health care.

Prescription drug coverage proposals have been discussed most recently in the context of Medicare beneficiaries; the largest group that requires access to prescription drugs yet lacks stable prescription drug coverage. ${ }^{127}$ These proposals tend to fall into one of two categories - those that would give subsidies to Medicare beneficiaries to purchase their own prescription drug insurance in the marketplace and those that would consolidate drug purchasing power for a given geographic area in one pharmacy benefits manager (PBM), chosen through competitive bidding every few years by the Health Care Financing Administration (HCFA) and regulated as a monopoly. ${ }^{128}$

Both the decentralized and centralized approaches have significant drawbacks. Under the regulated monopoly approach, there is the possibility of excessive government control over price and market share. ${ }^{129}$ The possibility is easiest to see in the case of a monopoly drug plan with a "closed" formulary - in other words, a monopoly drug plan that provides coverage only for drugs on the formulary list. Indeed, supporters

127. Medicare does not include coverage of outpatient prescription drugs as a basic benefit. Those beneficiaries who have coverage generally obtain it through a supplemental policy, by enrolling in a Medicare managed-care plan that includes prescription drug coverage, or through Medicaid. Only about fifty-three percent of Medicare beneficiaries have continuous drug coverage in any given year. See HHS REPORT, supra note 9, at 9. By contrast, virtually all individuals under sixty-five with health insurance have some drug coverage. See David E. Rosenbaum, Health Insurance Provides Buffer Against Drug Prices for Most Americans, N.Y. TIMES, June 1, 2000, at A17. Indeed, in inflationadjusted dollars, Americans with health insurance currently pay less out-of-pocket for drugs than they paid thirty years ago. To be sure, the forty-four million individuals who lack any health insurance also lack coverage for prescription drugs. See id. However, because these uninsured individuals are not elderly, they are less likely to suffer the acute and chronic conditions that need to be addressed by prescription drugs.

128. See Mark McClellan et al., Designing a Medicare Prescription Drug Benefit: Issues, Obstacles, and Opportunities, HeAlTH AFF., Mar.-Apr. 2000, at 28-29 (summarizing the features of six different proposals that have been put forward thus far). The proposals put forward by former President Clinton and presidential candidate Gore are essentially identical and fall into the regulated monopoly category. See Sheryl Gay Stolberg, No Simple Answers to Rising Costs of Drugs for the Elderly, N.Y. Times, Sept. 3, 2000, $\$ 1$ (Sunday, Late Edition), at 26.

129. A similar concern about excessive government control over price and market share might be raised by proposals in which the government acted as a purchasing agent for Medicare beneficiaries with incomes below a certain threshold. 
of the regulated monopoly approach caution against a closed formulary, noting that it would "put the government in the position of strongly influencing the market shares of various drugs."

Even under an open formulary system, however, there looms the possibility of the government influencing price in a manner that stifles innovation. Consider, for example, an open formulary proposal recently put forward by a group of Harvard economists who support a regulated monopoly model. ${ }^{131}$ Under the Harvard proposal, the PBM would achieve bargaining power with respect to price by using the lowest-price drug in a particular therapeutic class as the "reference" drug. While the price of that reference drug would be fully covered by insurance, the patient would have to pay the difference in price for any other drugs in the class. ${ }^{132}$ Although reference pricing creates the illusion of market-like choice, the key regulatory power, which is the power to define therapeutic classes, still rests with the government. In order to keep costs down, the government would presumably have an incentive to define broad classes, perhaps even classes encompassing drugs that differed significantly in their mechanism of action. Thus, for example, HCFA regulators might group generic tricyclic drugs (TCAs) with patented selective serotonin reuptake inhibitors (SSRIs) into a broad "antidepressant" class. In that situation, unless patients were willing to pay a surcharge for the SSRI, the patented SSRI drug manufacturer would have to drop its price down to the generic price in order to maintain market share. ${ }^{133}$

Further, as even supporters of such pricing admit, reference pricing would not work in those situations where a therapeutic class included only a single patented drug. ${ }^{134}$ In those contexts, HCFA or Congress would simply have to negotiate a price. Moreover, the bargaining power enjoyed by the government, coupled with government incentives to keep costs down, might produce a price that was well below the level necessary to stimulate innovation. In addition, because these negotiated drug prices would then become public (in contrast with private sector negotiated discounts, which are kept secret) private insurers might demand similar discounts. ${ }^{135}$

The regulated monopoly model clearly has problems. By the same token, a market-based model is hardly a panacea. Perhaps most importantly, any approach that relies on competition between insurance plans needs to address the reality of adverse selection. Left unregulated, com-

130. Haiden Huskamp et al., The Medicare Prescription Drug Benefit: How Will the Game Be Played?, Health AFF., Mar.-Apr. 2000, at 8, 13; see also Patricia Danzon, Pharmaceutical Benefit Management: An Alternative Approach, HEALTH AFF., Mar.-Apr. 2000, at 24 (discussing problems of monopsony).

131. See generally Huskamp et al., supra note 130.

132. See id. at 13 .

133. See Danzon, supra note 130 , at 25 (noting that evidence from other countries indicates that brand name prices typically fall to the reference price).

134. See Huskamp et al., supra note 130 , at 15.

135. See Stolberg, supra note 128, at 26. 
petition means that those who expect to spend more on prescription drugs are likely to seek out more generous plans, causing premiums for those plans to rise to prohibitive levels. ${ }^{136}$ Indeed, fears regarding rampant adverse selection have been expressed by insurers themselves. In recent Congressional testimony, the president of the Health Insurance Association of America warned that "w[e] do not believe that private drug-only insurance is a viable concept given the substantial economic and regulatory barriers and problems with adverse selection that would face such a product." 137

Adverse selection could be mitigated, however, through one of several fairly conventional regulatory approaches. One approach might involve a regulatory requirement that defined a certain minimal level of drug coverage required of all plans. For example, plans could be required to cover certain therapies that had proven to be highly costeffective when analyzed using standard techniques, discussed further below, ${ }^{138}$ of medical cost-effectiveness analysis. Because this regulatory requirement would be quite minimal, it would not give the government excessive control over drug development. Many plans could, and would, cover drugs that were less cost-effective. However, it would thwart plans from engaging in extreme risk selection by offering only the most minimal benefits. Adverse selection problems might also be mitigated through adjustment of federal subsidies based on medical risk. If plans received greater funding for individuals who were at greater risk - that is, consumed more drugs - their incentive to cherry pick would diminish. ${ }^{139}$ Finally, maintaining a small drug insurance subsidy, even for those who are relatively well off, would discourage adverse selection by providing an incentive for all healthy individuals, low-income and high-income to maintain insurance coverage. ${ }^{140}$ Thus, for example, a subsidy plan proposed by Senators John Breaux and Bill Frist provides a full subsidy to those below $135 \%$ of the poverty line who enroll in the least expensive plan in their area. Although the subsidy decreases for those above $150 \%$ of the poverty line, the Breaux-Frist proposal continues to subsidize at

136. See Huskamp et al., supra note 130, at 10-11. Indeed, the likelihood of adverse selection is the Achilles heel of choice-based plans for health care delivery. See Rai, supra note 11, at 1043. Conceivably, adverse selection could be a problem for the regulated monopoly approach. Seniors who were particularly healthy might opt out of any prescription drug plan. However, the large subsidies contemplated by regulated monopoly proposals, see McClellan et al., supra note 128 , at 28 (describing subsidies contemplated by Clinton plan), would likely create incentives for the vast majority of seniors to take advantage of prescription drug insurance.

137. Robin Toner, Fight Over Prescription Drug Benefits for Elderly Creates Unlikely Enemies, N.Y. TIMES, June 25, 2000, $\S 1$ (citing June 2000 testimony of Charles N. Kahn). Nevada's recent experience in requesting insurance companies to bid for providing prescription drug coverage to lowincome seniors appears to underscore Mr. Kahn's pessimistic predictions. The state's March 2000 invitation to hundreds of insurance companies was met with one response. See Robert Pear, Ominous Start for a Drug Plan for the Elderly, N.Y. TIMEs, July 8, 2000, at A1.

138. See infra notes $142-43$ and accompanying text.

139. E.g., Danzon, supra note 130, at 24; Rai, supra note 11, at 1042-43.

140. McClellan et al., supra note 128 , at 30. 
least $25 \%$ of the minimum actuarial plan value mandated by the proposal. ${ }^{141}$

The aforementioned suggestion that insurance companies be required to cover therapies that have been proven highly cost-effective would not only mitigate adverse selection, but it could also channel innovation in a direction that was likely to reduce health care costs (or, at a minimum, not increase those costs unduly). If medical innovation could be channeled properly, the fear, pervasive among health care scholars, that such innovation inevitably raises costs and exacerbates equity dilemmas, might be much reduced.

Medical cost-effectiveness analysis requires that the health benefits produced by a given intervention be compared with the intervention's cost. $^{142}$ Health benefits are usually measured in units called qualityadjusted life years (QALYs) and costs are generally measured from a societal perspective, so as to include all costs, current and future, related to prevention or treatment of disease as well as savings that might arise from its prevention or treatment. ${ }^{143}$ The best evidence to date suggests that drugs can differ quite dramatically in their effect on total health care cost. Thus an obvious mechanism for controlling cost would be to limit coverage to cost-effective drugs.

However, as matters currently stand, it is by no means clear that insurance coverage is focused on drugs that are cost-saving (in that they actually avert future morbidity and hence reduce health care costs) or costincreasing but nonetheless cost effective (i.e., although they increase total health care cost, the additional cost is merited given the additional health benefit produced). Between 1993 and 1998, the introduction of imitator, or "me-too," drugs in four relatively well-established categories-oral antihistamines, antidepressants, cholesterol-lowering drugs, and anti-ulcerants - accounted for almost one-third of pharmaceutical cost increases. ${ }^{144}$ The cost-effectiveness of me-too drugs, particularly in the aforementioned categories, is questionable. Although the me-too drug may prove more effective than the innovator drug for a certain population of patients, this marginal benefit is likely to be small. A small incremental benefit is particularly likely because many me-too drugs

141. See id. at 28 .

142. For valuable discussions of these techniques, see, for example, M.F. DRUMMOND ET AL., Methods for the Economic Evaluations of Health Care Programmes (1997); M.R. Gold ET AL., Cost EfFEctiveness In Health and Medicine (1996); M.C. Weinstein et al., Recommendations of the Panel on Cost-Effectiveness in Health and Medicine, 276 J. AM. MED. AsS'N 1253 (1996).

143. See Rai, supra note 11 , at 1048-49. In the case of pharmaceuticals, cost could be measured in one of two ways - by looking at the estimated cost of developing the drug (assuming, as is generally the case, that the marginal costs of production are negligible) or by looking at some "average" market cost. The two cost figures should be roughly equivalent - after all, in order for a pharmaceutical company to recoup its $R \& D$ investment, average market cost has to reflect, at least roughly, the cost of developing the drug. Moreover, difficult as an average market cost might be to determine (given the presence of price discrimination), it might be an easier figure to determine objectively than development cost.

144. See NIHCM REPORT, supra note 9, at ii. 
have thus far addressed illnesses (e.g., allergies) whose symptoms are relatively mild for a significant proportion of the population they affect.

To be sure, although me-too drugs do not confer much additional benefit, they can play some role in curbing price by limiting the scope of monopoly power enjoyed by any given patented drug. ${ }^{145}$ Nonetheless, significant reduction in price generally does not occur until a generic drug is introduced. ${ }^{146}$ This may be because me-too drugs are imperfect substitutes for the innovator drug (as well as for each other) and insured consumers and their physicians, who are generally insensitive to drug costs, do not tend to embrace imperfect substitution. ${ }^{147}$ Indeed, because consumers are cost-insensitive, their demand curve can be readily manipulated through advertising. A recent FDA survey determined that $13 \%$ of individuals who had seen a drug advertisement asked their doctor for a specific drug. ${ }^{148}$ The demand statistics from 1999 alone are quite telling. In 1999, the increase in sales of three widely promoted antiallergy drugs (Claritin, Zyrtec, and Allegra) accounted for $4.4 \%$ of the overall increase in drug spending. ${ }^{149}$ Increased sales of a single heavily promoted cholesterol-lowering drug (Lipitor) accounted for $5.5 \%$ of the total drug spending increase..$^{150}$

It should come as no surprise that insured consumers demand advertised medication, even when the medication has low benefit. What is more surprising is that many of these demands (about $50 \%$, according to the FDA survey) are met. ${ }^{151}$ As the $18 \%$ annual growth in pharmaceutical costs suggests, the managed care takeover has failed to spur significant cost-benefit tradeoffs, particularly (although not exclusively) in the area of pharmaceuticals. To be sure, managed care plans often give physicians financial incentives to practice parsimoniously. However, these incentives may apply only to specialist referrals and hospitalization, not pharmaceuticals. In addition, as Clark Havighurst and others have cogently argued, courts are unlikely to enforce insurance company contracts that restrict coverage based on cost-benefit calculations. ${ }^{152}$ Empiri-

145. CBO REPORT, supra note 14, ch. 3, at 9-10.

146. See id. ch. 3 , fig. 1 .

147. Cf. id. ch. 3 (noting that price competition among similar drugs is "softened because products are differentiated"). Indeed, there is some reluctance on the part of price-insensitive patients and physicians to embrace even perfect substitution in the form of a generic drug. See generally Linda Marsa, The Price We Pay: Consumers Remain Distrustful of Generic Medications, L.A. TIMES, Oct. 16, 2000, at S1 (noting that generic drug use appears to have reached a plateau at about forty percent of the total market).

148. Center for Drug Evaluation and Research, Food and Drug Admin., Attitudes AND BeHAVIORS ASSOCIATEd WITH DIRECT-TO-CONSUMER PROMOTION OF PRESCRIPTION DRUGS, (Spring 1999), available at http://www.fda.gov/cder/ddmac/research.htm (last visited Feb. 21, 2001) [hereinafter FDA SURVEY].

149. NiHCM Research Brief, Prescription Drugs and Mass Media Adyertising 3 (Sept. 2000), available at http://www.nihcm.org/DTCbrief.pdf.

150. Id. at 4

151. See FDA SURVEY, supra note 148.

152. E.g., ClaRK C. Havighurst, Health CARE Cholces 21-22 (1995); Elhauge, supra note 23, at 1550-51; see also Rai, supra note 11, at 1046-47. 
cal studies of coverage disputes indicate that, even in contexts where the dispute is over an experimental treatment of questionable benefit, courts often find for the insured. ${ }^{153}$ Moreover, physicians, and plans, that deliver care in a parsimonious fashion may be deemed to deviate from the custom-based standard of care and may, on that basis, be held liable in tort. ${ }^{154}$

It might be argued that although plans do not (and can not, given our current legal system) compete explicitly on the basis of cost-benefit tradeoffs, they can compete on price and on other measures of quality (e.g., scope of coverage; objective indicators of plan performance in providing preventive therapy and disease treatment; data on subjective patient satisfaction). Moreover, comparisons of plans on the dimensions of price and quality could serve as a proxy for more direct cost-benefit comparisons. Indeed, concerted efforts are currently being made by various "information intermediaries" - that is, employers and employer groups as well as federal and state governments - to present price and quality information to consumers in a comprehensible fashion. ${ }^{155}$ How-

153. See Mark A. Hall et al., Judicial Protection of Managed Care Consumers: An Empirical Study of Insurance Coverage Disputes, 26 SETON HALL L. REV. 1055, 1063 (1996); Mark A. Hall \& Gerard F. Anderson, Health Insurers' Assessment of Medical Necessity, 140 U. PA. L. REV. 1637 (1992). Notably, ERISA-governed insurance plans that explicitly gave discretion to the plan administrator appeared to fare better than plans not governed by ERISA. See Hall et al., supra, at 1066. On the other hand, empirical studies of decided cases suffer from a selection bias problem. The decided cases are not necessarily representative of the larger class of disputes. See generally William M. Sage, Judicial Opinions Involving Health Insurance Coverage: Trompe L'Oeil or Window on the World, 31 IND. L. REV. 49 (1998) (making this point). However, analysis of decided cases does provide some useful data.

154. Until recently, there was some uncertainty about the scope of tort liability faced by ERISAgoverned plans. However, the U.S. Supreme Court recently made it clear that state tort law can be used to challenge decisions that involve both treatment and coverage, even if the plan is governed by ERISA. See Pegram v. Herdich, 530 U.S. 211 (2000); see also M. Gregg Bloche \& Peter D. Jacobson, The Supreme Court and Bedside Rationing, 284 J. AM. MED. Ass'N 2776, 2777 (2000) (noting that, in Pegram, the Court "created an opening for myriad state law challenges to health plans' utilization management methods").

155. For a discussion of how information technology could be used to present comparative information on health plans, see Arti K. Rai, Reflective Choice in Health Care: Using Information Technology to Present Allocation Options, 25 AM. J.L. \& MED. 387 (1999). Many commentators argue that competition on nonprice dimensions will be difficult or impossible to achieve because individuals have difficulty making choices based on complex information. E.g., Russell Korobkin, The Efficiency of Managed Care "Patient Protection" Laws: Incomplete Contracts, Bounded Rationality, and Market Failure, 85 CORNell L. REv. 1, 52-60 (1999); William M. Sage, Regulating Through Information: Disclosure Laws and American Health Care, 99 COLUM. L. REv. 1701, 1728-31 (1999). As these commentators correctly point out, research from the behavioral economics literature demonstrates that individuals routinely misinterpret information, particularly probabilistic information about future events (such as future illness). See Rai, supra, at 394; Sage, supra, at 1729. Moreover, when choosing between different options, each of which has a number of different attributes, individuals often adopt inaccurate simplification strategies. For example, individuals may focus on one salient attribute and then select solely based on that attribute. See Korobkin, supra, at 52-54. Behavioral economics poses an important challenge to a choice-based approach. However, the challenge is hardly insurmountable. As various researchers have pointed out, even if any given consumer's choice is based on a single salient attribute, an efficient market can result if these salient attributes vary across consumers. E.g., David M. Grether et al., The Irrelevance of Information Overload: An Analysis of Search and Disclosure, 59 S. CAL. L. REv. 277, 300-01 (1986) (noting that "if a substantial number of consumers shop for attributes in which they are interested, the full set of salient attributes will be supplied at competi- 
ever, the extent to which plans can engage in price/quality competition based on true cost-benefit tradeoffs (as contrasted with cost reduction that has no effect on benefit) is still limited by the structure of contract and tort law. Limitations on quality that emerge from limitations of beneficial coverage will be difficult to implement in our current system.

Some might argue that impediments to competition based on costbenefit tradeoffs should not eliminate pressures to create at least certain types of cost-effective drugs. Insurance companies want to keep their expenditures low and thus presumably have an incentive to cover drugs that will avert future morbidity at a relatively low cost. However, insurance plan incentives are not optimal. Because individuals change plans with some frequency, insurance companies do not internalize all of the costs and benefits of the health care they provide. Thus insurance companies may not be inclined to cover drugs that are medium to high cost in the short term, even if these drugs are highly cost-effective in the long term because they avert future disability and hence future health care costs. Conversely, insurance companies may be inclined to cover relatively low-cost, low-benefit drugs that have high visibility for consumers (e.g., Claritin and the like). For all of these reasons, a regulatory requirement mandating provision of cost-effective drug therapy may be desirable, particularly if compliance with the regulatory mandate could be raised as a defense in contract and tort lawsuits.

Of course, a regulatory mandate will require information regarding which drugs (or categories of drugs) are cost-effective. One of the problems with our current medical technology regime is that such information is woefully lacking. ${ }^{156}$ In theory, given the extended FDA approval process, cost-effectiveness data on drugs, or categories of drugs, should be easier to gather than data on other medical technology. However, at least as matters currently stand, much of the relevant data is collected and presented by self-interested pharmaceutical companies. ${ }^{157}$ As contrasted with pharmaceutical company studies, objective cost-effectiveness

tive price-quality levels"). In addition, as Korobkin acknowledges, neoclassical economists have long defended against claims of limited consumer comprehension by noting that efficiency can result even if only "a sizable minority of consumers are rational maximizers with a sophisticated understanding of their purchase options." Korobkin, supra, at 60 . Because sellers will want to compete for the business of these sophisticated consumers, sophisticated consumers will discipline the market as a whole. To be sure, the sophisticated consumer constraint may have less force in health care markets, where sophisticated consumers may be individuals with severe illness - that is, precisely the sorts of individuals that insurers want to avoid. However, this latter point is essentially a subset of the larger adverse selection problem presented by health insurance. As discussed in the text, the adverse selection problem can be addressed through mandated benefits and risk adjustment.

156. E.g., I. Steven Udvarheyli et al., Cost-Effectiveness and Cost-Benefit Analyses in the Medical Literature: Are the Methods Being Used Correctly?, 116 ANNALS INTERNAL MED. 238 (1992) (discussing methodological problems with cost-effectiveness studies that have been done).

157. Peter J. Neumann et al., Are Pharmaceuticals Cost-Effective? A Review of the Evidence, HEALTH AFF., Mar.-Apr. 2000, at 92, 96, 97 (discussing disagreements about the cost-effectiveness of pharmaceuticals). As a consequence, there is no consensus on the cost-effectiveness of many pharmaceuticals. E.g., J.D. Kleinke, Just What the HMO Ordered: The Paradox of Increasing Drug Costs, HEALTH AFF., Mar.-Apr. 2000, at 78, 79; Neumann et al., supra, at 92, 93. 
data is a public good, and we may need public funding to generate this good. ${ }^{158}$

Finally, it might be argued that there is a tension between urging that the government impose a regulatory requirement of costeffectiveness and also urging that the government make no effort to set price. This tension would indeed be present if the regulatory requirement were in any sense a ceiling on what plans could offer. Drug companies would then be compelled to set their prices in a manner that met the cost-effectiveness requirement, even if that meant they could not recover R\&D costs. However, because the regulatory requirement would be a minimal floor rather than a ceiling, most plans would presumably cover some drugs that did not meet the requirement. To put the point another way, the regulatory requirement would simply ensure a very robust market for those drugs that were highly cost-effective. It would not preclude a market for other drugs.

On balance, a market-oriented program that is properly designed probably poses fewer difficulties than the regulated monopoly approach. Either option is preferable, however, to the current system, where the uninsured elderly, a disproportionate percentage of whom are poor, pay more for drugs than do insurance plans.

\section{CONCLUSION}

In the context of prescription drugs, the inevitable tension between stimulating innovation and preserving access creates serious equity concerns that are simply not present in other contexts. This paper has identified some promising mechanisms for relieving this tension. One such mechanism, often ignored by intellectual property scholars, is the simple, and emphatically low-technology, remedy of insurance. Because of the manner in which the health care industry is structured, providing access to insurance is a low-cost mechanism for reducing deadweight loss. At the other end of the technology spectrum, there is the growing science of genomics. Although genomics should increase the importance of prescription drugs in health care, and thus might threaten to exacerbate equity concerns, it may also provide ways to produce these drugs more efficiently than before. To the extent that the biotechnology and pharmaceutical industries can internalize fully the efficiency benefits of digital technology, reforms that align the structure of intellectual property protection for pharmaceuticals more closely with that of other innovation might be considered. Equally important will be regulation that imposes cost-effectiveness requirements on pharmaceutical innovation.

158. To be sure, cost-benefit and cost-effectiveness analyses are highly controversial. A full discussion of the merits and limits of such analyses (and of the proper methods for conducting such analyses) is beyond the scope of this paper. However, most observers agree that such analyses should play at least some role in allocation decisions. 
If innovations in genomics can be channeled in a cost-effective direction, we may yet see a time when Moore's law provides not simply faster and cheaper computers but also a more equitable health care system. 